\title{
Review \\ Polyhydroxyalkanoates (PHAs) as Biomaterials in Tissue Engineering: Production, Isolation, Characterization
}

\author{
Dana-Maria Miu ${ }^{1,2}$, Mihaela Carmen Eremia ${ }^{1, * \mathbb{C}}$ and Misu Moscovici ${ }^{1}$ \\ 1 The National Institute for Chemical Pharmaceutical Research \& Development, 031299 Bucharest, Romania; \\ dana.miu92@gmail.com (D.-M.M.); misu_moscovici@hotmail.com (M.M.) \\ 2 Faculty of Applied Chemistry and Materials Science, University Politehnica of Bucharest, \\ 011061 Bucharest, Romania \\ * Correspondence: mihaelaceremia@yahoo.com
}

Citation: Miu, D.-M.; Eremia, M.C.; Moscovici, M. Polyhydroxyalkanoates (PHAs) as Biomaterials in Tissue Engineering: Production, Isolation, Characterization. Materials 2022, 15, 1410. https://doi.org/10.3390/ ma15041410

Academic Editor: Joaquim Miguel Oliveira

Received: 10 December 2021

Accepted: 7 February 2022

Published: 14 February 2022

Publisher's Note: MDPI stays neutral with regard to jurisdictional claims in published maps and institutional affiliations.

Copyright: (C) 2022 by the authors. Licensee MDPI, Basel, Switzerland. This article is an open access article distributed under the terms and conditions of the Creative Commons Attribution (CC BY) license (https:// creativecommons.org/licenses/by/ $4.0 /)$.

\begin{abstract}
Polyhydroxyalkanoates (PHAs) are biodegradable and biocompatible biopolymers. These biomaterials have grown in importance in the fields of tissue engineering and tissue reconstruction for structural applications where tissue morphology is critical, such as bone, cartilage, blood vessels, and skin, among others. Furthermore, they can be used to accelerate the regeneration in combination with drugs, as drug delivery systems, thus reducing microbial infections. When cells are cultured under stress conditions, a wide variety of microorganisms produce them as a store of intracellular energy in the form of homo- and copolymers of [R]—hydroxyalkanoic acids, depending on the carbon source used for microorganism growth. This paper gives an overview of PHAs, their biosynthetic pathways, producing microorganisms, cultivation bioprocess, isolation, purification and characterization to obtain biomaterials with medical applications such as tissue engineering.
\end{abstract}

Keywords: polyhydroxyalkanoates; microbial fermentation; isolation; purification; characterization

\section{Introduction}

The currently increasing interest in polyhydroxyalkanoates (PHA) research for various applications [1] is due to their biodegradability [2,3], biocompatibility [4], bioresorbability [5] and piezoelectricity [1]. Furthermore, their various chemical properties have made them the topic of several scientific studies. As other biopolymers, they are environmentally friendly alternatives to non-biodegradable synthetic materials that have a negative impact on the environment [6]. PHAs are produced by a wide range of microorganisms under stress conditions of fermentation media composition, with a high concentration of carbon source, and the rest of the nutrients are present in limited quantities (nitrogen, phosphorus, potassium, magnesium or oxygen) $[7,8]$. Depending on the carbon source, the microorganisms make intracellular energy reserves under stress conditions in the form of homo- or copolymers of [R]-hydroxyalkanoic acids. PHAs have attracted interest as biodegradable polymers due to their biological (microbial) origin and non-toxic nature when compared to synthetic plastics, which can be highly toxic. The most-studied PHA is polyhydroxybutyrate (PHB) [9], and the most recently known is PHA, namely, polyhydroxyoctanoate (PHO) [10]. While PHB can be produced on an industrial scale, the production of $m c l$-PHA is still inferior to scl-PHA production due to the toxicity of the substrate. PHB has been studied in biomedical applications due to its thermoplastic behavior, suitable mechanical properties and versatile sintering methods [11]. Many studies have confirmed that $m c l$-PHA can be much more flexible and resistant than $s c l$-PHA. These properties make it a good option for use in many fields, especially in the medical field or in obtaining films and coatings. PHA can be effective as a raw material in producing tablets, nanoparticles or drug scaffolds due to its pleasant physical properties and high biocompatibility [12]. PHA obtained under controlled conditions and with high purity can be used in tissue engineering through therapeutic applications such as vascular grafts, nerve tissue, or as a 
scaffold to promote cell growth by supplying nutrition $[13,14]$. This review considers the leading medical representatives of PHAs in tissue regeneration engineering in recent years, particularly focusing on the production, isolation and characterization of such biopolymers.

\section{Structure and Properties of Polyhydroxyalkanoates}

Polyhydroxyalkanoates (Figure 1) make up a class of very versatile compounds, in which over 100 polymers have been shown to date, differing by the number of carbon atoms in the main chain or the radical $\mathrm{R},[15,16]$, according to the formula, as seen in Table 1 [17]:

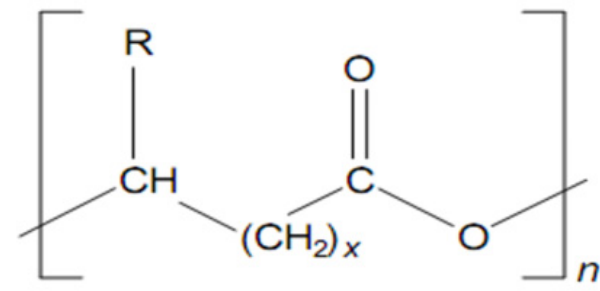

$$
\mathrm{n}=100-30,000
$$

Figure 1. Structure of polyhydroxyalkanoates (PHAs).

Table 1. PHAs types.

\begin{tabular}{|c|c|c|c|c|c|}
\hline$X$ & $\begin{array}{c}\mathrm{R} \\
\text { (Radical) }\end{array}$ & $\begin{array}{l}\text { Monomer } \\
\text { Name }\end{array}$ & $\begin{array}{l}\text { Monomer } \\
\text { Add. }\end{array}$ & $\begin{array}{c}\text { Polymer } \\
\text { Name }\end{array}$ & $\begin{array}{c}\text { Polymer } \\
\text { Add. }\end{array}$ \\
\hline \multirow[t]{10}{*}{1} & $\mathrm{H}$ & 3-hydroxypropionate & $3 \mathrm{HP}$ & Poly-(3-hydroxypropionate) & 3РHP \\
\hline & $\mathrm{CH}_{3}-$ & 3-hydroxybutyrate & $3 \mathrm{HB}$ & Poly-(3-hydroxybutyrate) & 3PHB \\
\hline & $\mathrm{CH}_{3}-\mathrm{CH}_{2}-$ & 3-hydroxyvalerate & $3 \mathrm{HV}$ & Poly-(3-hydroxyvalerate) & 3PHV \\
\hline & $\mathrm{CH}_{3}-\mathrm{CH}_{2}-\mathrm{CH}_{2}-$ & 3-hydroxycaproate & $3 \mathrm{HC}$ & Poly-(3-hydroxyhexanoate) & $3 \mathrm{PHC}$ \\
\hline & $\mathrm{CH}_{3}-\left(\mathrm{CH}_{2}\right)_{2}-\mathrm{CH}_{2}-$ & 3-hydroxyheptanoate & $3 \mathrm{HH}$ & Poly-(3-hydroxyheptanoate) & $3 \mathrm{PHH}$ \\
\hline & $\mathrm{CH}_{3}-\left(\mathrm{CH}_{2}\right)_{3}-\mathrm{CH}_{2}-$ & 3-hydroxyoctanoate & $3 \mathrm{HO}$ & Poly-(3-hydroxyoctanoate) & $3 \mathrm{PHO}$ \\
\hline & $\mathrm{CH}_{3}-\left(\mathrm{CH}_{2}\right)_{4}-\mathrm{CH}_{2}-$ & 3-hydroxynonanoate & $3 \mathrm{HN}$ & Poly-(3-hydroxynonanoate) & $3 \mathrm{PHN}$ \\
\hline & $\mathrm{CH}_{3}-\left(\mathrm{CH}_{2}\right)_{5}-\mathrm{CH}_{2}-$ & 3-hydroxydecanoate & $3 \mathrm{HD}$ & Poly-(3-hydroxydecanoate) & 3PHD \\
\hline & $\mathrm{CH}_{3}-\left(\mathrm{CH}_{2}\right)_{6}-\mathrm{CH}_{2}-$ & 3-hydroxyundecanoate & $3 \mathrm{HUD}$ & Poly-(3-hydroxyundecanoate) & 3PHUD \\
\hline & $\mathrm{CH}_{3}-\left(\mathrm{CH}_{2}\right)_{7}-\mathrm{CH}_{2}-$ & 3-hydroxydodecanoate & $3 \mathrm{HDD}$ & Poly-(3-hydroxydodecanoate) & 3PHDD \\
\hline 2 & $\mathrm{H}$ & 4-hydroxybutyrate & $4 \mathrm{HB}$ & Poly-(4-hydroxybutyrate) & $4 \mathrm{PHB}$ \\
\hline 3 & $\mathrm{H}$ & 5-hydroxyvalerate & $5 \mathrm{HV}$ & Poly-(5-hydroxyvalerate) & $5 \mathrm{PHB}$ \\
\hline
\end{tabular}

The PHA structure is differentiated according to two criteria:

(a) The structure of the radicals attached to the carbon atoms with the R configuration in the skeleton of the polymer chain; these radicals represent the side chain of monomeric hydroxy acids;

(b) The number and structure of the monomers in the polymer chain.

Depending on the number of $\mathrm{C}$ atoms in the hydroxy acid side chain (monomer), bacterial PHAs can be divided into three groups [18], namely:

- $\quad$ PHA is made up of monomers with 3-5 carbon atoms and called PHA with short side chains, scl-PHA (short-chain-length-PHA);

- $\quad$ PHA is composed of monomers with 6-14 C atoms and called PHA with medium side chains, mcl-PHA (medium-chain-length-PHA); 
- $\quad$ PHA is composed of mixed monomers, both with a short side chain (3-5 C atoms) and a long one (6-14 C atoms), called scl-mcl-PHA and later discovered in the first two categories.

The physical properties of these polymers are strictly dependent on the structure of the monomers of which they are composed [19]. Hence the conclusion that, by incorporating monomers with different numbers of $\mathrm{C}$ atoms, biodegradable polymers with an extensive range of properties and uses varying can be obtained [20-22].

Depending on the number and structure of the component monomers, PHAs can be homopolymers, copolymers or terpolymers.

The prototype of this family of polyesters, polyhydroxybutyrate (PHB), was discovered by Lemoigne in 1927 at the Pasteur Institute in Paris as a constituent of the bacterium Bacillus megaterium and had similar properties to polypropylene and polyethylene, including flexibility and excellent strength. PHB is presented as a dextrorotatory helix with two turns located at a distance of $5.95 \AA$. Interactions between carbonyl-methyl groups stabilize the conformation of the helix. Thus, one of nature's few exceptions does not rely on the hydrogen bond [23].

PHB can have an average molecular weight of 0.1-3 MDa, although, for processing, the molecular masses must be between 200 and $800 \mathrm{kDa}[24,25]$.

PHAs are predominantly produced by many bacteria as an intracellular energy reserve when cells are cultured under stress condition as a series of homo- and copolymers of $[R]-\beta$-hydroxyalkanoyl acids, depending on the source of $C$ used to grow microorganisms.

Depending on the molecular structure, PHAs can have different physico-chemical properties, and thermal stability is essential in using the polymer in various applications because PHA is sensitive to heat [26]. Scl-PHA type and its copolymers are semi-crystalline polymers with a high melting temperature, and mcl-PHA have lower melting temperature and are highly elastomeric [27]. Scl-PHA has a higher melting temperature than $m c l$-PHA due to a high degree of crystallization from the polymer matrix [28,29]. Mcl-PHA polymers are a better choice for medical applications due to their better thermo-mechanical properties, with a melting temperature between 39 and $61^{\circ} \mathrm{C}$, and are even more flexible and elastic than scl-PHA [30]. The polymer P (3HB) and its copolymer P (3HB-co-3HV) with low HV content are known to be more rigid and have a low impact resistance due to the relatively high crystallinity of the material and the appearance of the second crystallinity that occurs after the material's aging process [31].

Poly (3-hydroxybutyrate-co-3-hydroxyvalerate) (PHBV) degradation is faster than PHB. The degradation kinetics of biopolymers depend on the processing conditions, and, therefore, on the structure (copolymer or homopolymer) and crystallinity [32]. Commercially available PHB and PHBV have different trade names: Biopol ${ }^{\circledR}$ (Monsanto, MI, USA), Nodax ${ }^{\circledR}$ (Procter \& Gamble, Cincinnati, OH, USA), PHBH $^{\circledR}$ (Kaneka Corporation, Tokyo, Japan), Eamat ${ }^{\circledR}$ (Tianan, Ningbo, China) and Biomer $\mathrm{P}^{\circledR}$ from Biomer (Bayern, Germany) [33], as well as GalaFLEX ${ }^{\circledR}$ (Galatea-Tepha, Lexington, MA, USA) [34].

PHAs are biocompatible for various reasons, the most important of which is that PHAs are found everywhere, not only in microorganisms as a carbon and energy storage material, but also in plants and animals in the form of low-molecular-weight PHA [35]. The chemical composition of PHA is also essential so that the degree of purity can affect the biocompatibility feature of the polymer [36]. Studies have shown that inflammatory reactions due to the importance of the material purity were found in a scl-PHA copolymer, tested in vivo on laboratory animals so that the impurities migrated into the surrounding tissue [37]. Another valuable property in biomedical applications of PHA is biodegradability. In the natural environment, it is degraded by microbial depolymerization, and when implanted in the body, in vivo, it can be degraded by enzymatic and hydrolysis mechanisms. Lipase can be considered the main enzyme responsible for biodegrading PHA types (scl- and $\mathrm{mcl}_{-}$) in the body [38]. 


\section{Production PHA}

\subsection{Biological Synthesis}

PHAs biosynthesis comprises two enzymatic steps: monomer intake and the polymerization of previously generated monomer units. To make PHA production more efficient, it is necessary to express the metabolic pathways regarding monomers integration into biosynthesis processes. All the substrate monomers for polymerization are derived from fatty acid metabolism in biosynthesis and elongation processes, except for acetyl-CoA synthesis. In conclusion, monomer-targeting enzymes are described as being related to the specific substrate.

The combination of genetic engineering techniques and fermentation technologies led to high poly-(R)-3-hydroxybutyrate production. The copolymerization of 3PHB with larger chains of 3-hydroxyalkanoate provides the product's superior physical properties, ductility and strength compared to PHB homopolyester. As a result, understanding the compositional diversity of the integrated monomers is critical. This may be adjusted based on the metabolic routes used for monomer intake. A bacterium (such as Ralstonia eutropha), when supplemented with different precursors, can synthesize PHB and different copolymers. By genetic engineering, it is possible to greatly control the produced polymer. It has been shown that Escherichia coli strains, together with PHA-negative nutrients, are used as hosts, and more than 100 examples of genetic engineering are described for performance in this area. [18,39-41]

\subsubsection{Metabolic Pathways for PHA Biosynthesis}

In recent years, it has become apparent that different metabolic pathways can contribute to screening PHA monomers. The metabolic pathways for PHA biosynthesis are multiple and their biosynthesis by microorganisms is dependent on the carbon source in the environment. "Related" carbon sources produce hydroxyalkanoate monomers with a similar chemical structure, while "unrelated" sources generate hydroxyalkanoate monomers with a completely different structure. The metabolic pathways are specific for each microorganism, describing three metabolic pathways to which the enzymatic participation of acetyl-CoA is common.

Metabolic pathway I is the most common and generates hydroxybutyrate monomers with the participation of acetyl-CoA.

Metabolic pathway II generates PHA from fatty acids and can form various hydroxyalkanoate monomers for PHA biosynthesis. The use of fatty acids by bacteria requires the coordination of $\beta$-oxidizing enzymes and a fatty acid transport system. By the $\beta$-oxidation of fatty acids, a corresponding conversion with the genetic inheritance of the microorganism must take place.

Some medium- and long-chain PHA fatty acid bacteria must form 3-hydroxy acyl-CoA from glucose and other unrelated carbon sources. Therefore, the biosynthesis of PHA from glucose in these bacteria is related to the biosynthesis of fatty acids (metabolic pathway III).

It has been shown that some Pseudomonas species grown on unrelated carbon sources predominantly accumulate 3-hydroxydecanoate monomers and other minor constituents such as 3-hydroxyhexanoate and 3-hydroxyoctanoate.

The similarity in the composition of PHA generated from different carbon sources shows the presence of a common intermediary in the substrate's metabolism, most likely acetyl-CoA.

The manufacture of multiple distinct monomers for the biosynthesis of PHAs from unrelated carbon sources and simple carbon sources is a significant cost factor in PHA production.

Pseudomonas sp. Are best known and used as producers of PHAs because they can perform their biosynthesis from various carbon sources, including n-alkanes, n-alkenes, alkanoic acids and alkenoic acids. 
Intermediates in the biosynthesis of fatty acid PHAs must convert the acyl carrier protein to the CoA form. Recently, it was found that the phaG gene was involved in this conversion, and the existence of this enzyme was anticipated a long time ago.

The discovery of acyl-ACP-CoA transacylase connects fatty acid production to PHA biosynthesis [42-44].

The metabolic pathways for the supply of various hydroxydecanoate monomers are presented in Figure 2.

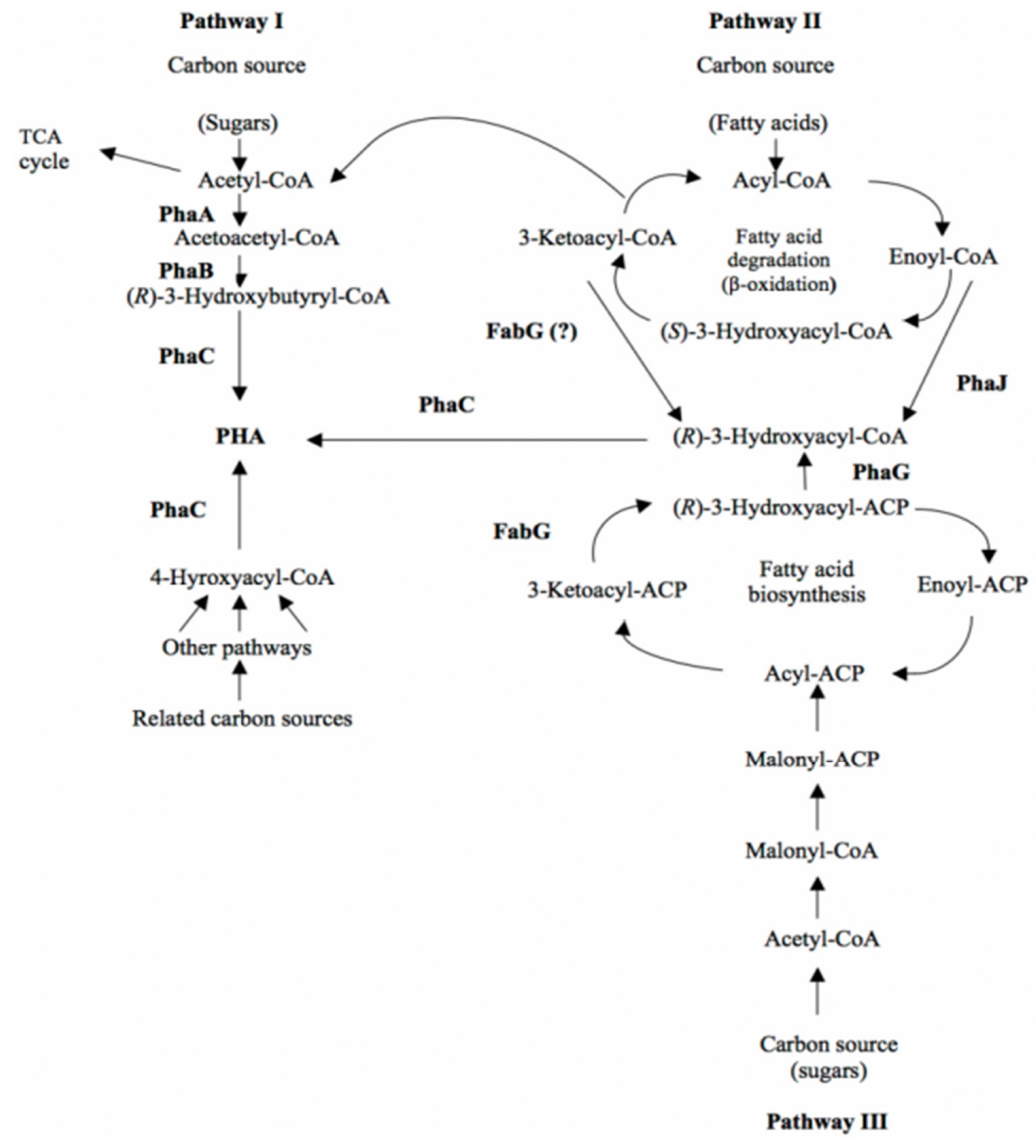

Figure 2. Metabolic pathways of PHAs biosynthesis (Ref. [45], Available online: https://www. ecobiomaterial.com/pha/ accessed on 1 December 2021).

\subsubsection{Microorganisms Producing PHA}

Poly-3-hydroxyalkanoates are intracellularly reported as energy substances stored by a wide range of bacteria. Obtaining them is conditioned by limiting the nitrogen source in the fermentation medium, but the limitation of the carbon source and the phosphates was also studied [46].

The bacterial productivity of polyhydroxyalkanoates is influenced by various parameters, including the carbon source/nitrogen source ratio, cultivation duration, temperature, $\mathrm{pH}$, and the presence of macro- and microelements [47].

Many bacteria have the property of storing the energy and skeletons of carbon atoms as biodegradable compounds with polymeric structures and properties similar to synthetic plastics. However, very few can produce or accumulate these polymers in industrially valuable quantities $[48,49]$. Among the microorganisms capable of producing PHAs, the most-studied were Pseudomonas oleovorans [46,50], Pseudomonas aeruginosa [51] and Pseudomonas putida [39], Ralstonia eutropha, as well as Chlamydomonas reinhardtii transformed with two expression vectors, including one from Ralstonia eutropha [50]. Genes for about 30 PHA synthases and, therefore, for several PHA biosynthesis pathways have been cloned, and many of them have been analyzed [46,52-54]. 
Various fermentation methodologies, including batch, fed-batch, and continuous processes, were used to achieve a high-biomass PHA production. Finding the best-suited carbon source might help to increase polymer output. Table 2 summarizes the bacterial strains that were employed to manufacture PHA, their initial carbon sources, and the (co)-polymers that were produced.

Table 2. Biosynthesis of PHA by various microorganisms.

\begin{tabular}{|c|c|c|c|c|}
\hline Microorganism & Carbon Source & $\begin{array}{c}\text { PHA Content } \\
\text { (\% Cell Dry Mass) }\end{array}$ & $\begin{array}{c}\text { PHA } \\
\text { Monomer } \\
\text { or Polymer }\end{array}$ & References \\
\hline Alcaligenes latus & $\begin{array}{c}\text { Sucrose, } \\
\text { mart, soy waste, milk waste sesame oil }\end{array}$ & 31.0 & Р3HB & {$[55,56]$} \\
\hline mAzotobacter chroococcum & wastewater from olive oil mills & 80 & $\begin{array}{c}\text { P3HB } \\
\text { P[HB-co-HV] }\end{array}$ & {$[39,57]$} \\
\hline Azotobacter beijerinckii & Glucose & 24.8 & P3HB & [58] \\
\hline Bacillus megaterium & $\begin{array}{c}\text { Citric acid, glucose, } \\
\text { glycerol, succinic acid, octanoic acid }\end{array}$ & $3.0-48.0$ & $\begin{array}{c}\text { P3HB, } \\
\text { scl-mcl-PHA, } \\
\text { mcl-PHA }\end{array}$ & [59] \\
\hline various Bacillus spp. type strains & $\begin{array}{l}\text { Acetate, valerate } \\
\text { 3-hydroxybutyrate, } \\
\text { propionate, sucrose, }\end{array}$ & $2.2-47.6$ & $\begin{array}{l}\text { 3HB, 3HV, } \\
\text { 3HHx }\end{array}$ & {$[39,60]$} \\
\hline Corynebacterium glutamicum & $\begin{array}{l}\text { Acetic acid, citric acid, glucose, } \\
\text { glycerol, succinic acid }\end{array}$ & $4.0-32.0$ & $\begin{array}{c}\text { P3HB, } \\
\text { mcl-PHA }\end{array}$ & [59] \\
\hline Corynebacterium hydrocarboxydans & Acetate, glucose & $8.0-21.0$ & $3 \mathrm{HB}, 3 \mathrm{HV}$ & [18] \\
\hline Cupriavidus necator (formerly & Glucose & 76.0 & P3HB & {$[61]$} \\
\hline $\begin{array}{c}\text { Hydrogenomonas eutropha, } \\
\text { Alcaligenes eutrophus, Ralstonia } \\
\text { eutropha and Wautersia eutropha) }\end{array}$ & $\begin{array}{l}\text { Potato starch, } \\
\text { saccharified } \\
\text { Waste }\end{array}$ & 46.0 & P3HB & {$[62]$} \\
\hline Escherichia coli mutants & $\begin{array}{c}\text { Glucose, glycerol, palm oil, sucrose, } \\
\text { molasses }\end{array}$ & & (UHMV)Р3НВ & {$[39,40]$} \\
\hline Halomonas boliviensis & $\begin{array}{l}\text { Hydrolyzed starch, } \\
\text { maltose }\end{array}$ & 56.0 & P3HB & {$[39,63]$} \\
\hline Haloferax mediterranei & Whey sugars & 72.8 & $\begin{array}{l}\text { P-(3HB-co- } \\
\text { 3HV) }\end{array}$ & [64] \\
\hline Pseudomonas aeruginosa & $\begin{array}{l}\text { Glucose, technical oleic acid, waste } \\
\text { free fatty acids, waste free flying oil }\end{array}$ & 25.0 & mcl-PHAs & {$[39,49,65]$} \\
\hline Pseudomonas fluorescens & Citric acid, glucose, fatty acids & $28.17-39.01$ & mcl-PHA & {$[65,66]$} \\
\hline Pseudomonas mendocina & 1,3-Butanediol, octanoate & $13.5-19.3$ & scl-mcl-PHA & {$[67]$} \\
\hline Pseudomonas oleovorans & 4-Hydroxyhexanoic acid & 18.6 & scl-mcl-PHA & {$[39,51,56]$} \\
\hline Pseudomonas putida & $\begin{array}{l}\text { Glucose, octanoic acid, undecenoic } \\
\text { acid }\end{array}$ & $61.8-67.1$ & mcl-PHA & {$[65,68]$} \\
\hline \multirow{3}{*}{ Pseudomonas putida KT2440 } & Glucose & 32.1 & mcl-PHA & {$[69]$} \\
\hline & 4-Hydroxyhexanoic acid & $25.3-29.8$ & mcl-PHA & [70] \\
\hline & Nonanoic acid & $26.8-75.4$ & mcl-PHA & {$[71]$} \\
\hline Pseudomonas stutzeri & $\begin{array}{c}\text { Glucose, soybean oil, alcohols, } \\
\text { alkanoates }\end{array}$ & $21-65$ & mcl-PHA & {$[39,72]$} \\
\hline Thermus thermophiles & Whey & 35.6 & scl-mcl-PHA & [73] \\
\hline $\begin{array}{c}\text { Various Streptomyces spp. type } \\
\text { culture }\end{array}$ & Glucose, malt, soy waste, sesame oil & $1.2-82.0$ & P3HB & {$[39,60]$} \\
\hline
\end{tabular}


Cupriavidus necator (also known as Ralstonia eutropha or Alcaligenes eutrophus) [74,75] is the strain that has received the most attention for its ability to produce PHAs. Imperial Chemical Industries (ICI plc) was the first to employ this bacterial strain to manufacture PHBV copolymer under the brand name Biopol. Bacillus spp., Alcaligenes spp., Pseudomonas spp., Escherichia coli, and Halomonas boliviensis are some other notable bacterial species that have recently been researched. [39,63].

During the production of biopolymers, the production of spores is also favored, to the detriment of the production of biopolymers, because of environmental conditions. Genetic engineering is a powerful tool in optimizing microbial metabolism to polymer production. Therefore, mutants that do not form Bacillus spores have been studied to increase their potential to produce PHA. In addition, Escherichia coli strains [76] were genetically engineered to manufacture PHB with an $\mathrm{M}_{\mathrm{w}}$ of up to $10^{7} \mathrm{Da}$ from glucose. This ultra-high-molecular-weight PHB (UHMW-PHB) can be formed into extremely strong films [77].

\subsubsection{Cultivation and Product Biosynthesis Media}

Usable substrates for PHA generation can be classified into three types based on the role they can perform throughout the fermentation process [41]:

- Substrates that support both cell growth and Poly (3HA) production;

- Substrates that support cell growth but not the production of Poly (3HA);

- Substrates that do not support cell growth but support the production of Poly (3HA).

Sugars, alkanes, fatty acids, and carbohydrates are the most commonly used carbon sources in the production of PHA. [78]. Wastes that are renewable carbon sources, such as acetate, frying or cooking oil, crude glycerol, molasses, and wastewater, could also be carbon sources [79].

The required conditions (carbon source, nutrients) for the accumulation of PHA differ depending on the bacteria and the carbon source. In a culture with limited nutrients and abundant carbon sources, some bacteria accumulate PHA (Cupriavidus necator, Protomonas extorquens). However, some accumulate PHA during the growth period without restricting an important nutrient (recombinant Escherichia coli, Alcaligenes latus) [80-82].

The carbon source used determines the type of PHA that is produced due to the substrate specificity of the enzymes involved in the metabolic pathway of biopolymers [79]

The most common type of PHA produced by microorganisms is poly-3-hydroxybutyrate, a short-chain homopolymer also called poly-D-(-)-3-hydroxybutyric acid, P (3HB) or PHB. Some heterotrophic microorganisms produce it in a well-defined culture media and batch or fed-batch cultures.

Ralstonia eutropha DSM 428 (H16) is the microorganism chosen by the Imperial Chemical Industries-Agricultural Division (ICI) for the commercial production of polyhydroxybutyrateco-polyhydroxy valerate: $\mathrm{PHB} / \mathrm{HV}, \mathrm{PHBV}, \mathrm{P}(3 \mathrm{HB}-3 \mathrm{HV})$ from glucose and propionic acid under nitrogen-limiting conditions. This copolymer has improved qualities compared to PHB.

When the carbon source is glucose, Alcaligenes eutrophus NCIB 11599 produces an amount of $5.08 \mathrm{~g} / \mathrm{L}$ PHA, with a PHA content of 54\% compared to dry biomass [83]. Alcaligenes eutrophus ATCC 33500 also produces an amount of $4.16 \mathrm{~g} / \mathrm{L}$ PHA on glucose, with a PHA content of $60 \%$ compared to dry biomass.

Generally, Ralstonia eutropha does not use glucose, but Ralstonia eutropha DSM 545 can use glucose as a mutant of Ralstonia eutropha DSM 529. When the carbon source is glucose $(1 \%)$, under the conditions of its supplementation with black grain bean broth containing carbohydrates, proteins, fiber, calcium, iron, magnesium, potassium, zinc, copper; aeration of the culture by shaking the flasks at $160 \mathrm{rpm}$ for $48-52 \mathrm{~h}$ and culture growth at $30{ }^{\circ} \mathrm{C}$, the Ralstonia eutropha (Cupriavidus necator) DSM 545 bacterium produces, at the end of cultivation, a PHB concentration of $0.23 \mathrm{~g} / \mathrm{L}$, (representing 34\% of the cell dry weight) up to $2.06 \mathrm{~g} / \mathrm{L}$ (representing $76 \%$ of the cell dry weight). The authors noted that PHB 
biosynthesis occurs simultaneously with biomass accumulation. However, even though the yield of PHB from dry biomass is $76 \%$, cell and PHA concentrations remain low [83,84].

Regarding the culture medium for Ralstonia eutropha DSM 545, the DSM/Catalogue 1998 [Catalogue of strains DSMZ, 6th edition, Ralstonia eutropha (Alcaligenes eutrophus) DSM 545. Medium 1 or 81: Pg. 138, (Medium 1: P. 307), (Medium 81: P. 311)] described the following media for this microorganism: medium 1 (nutrient agar, usable for culture maintenance) and medium 81, usable for growth: chemolithotrophic (in the atmosphere of $2 \% \mathrm{O}_{2}, 10 \% \mathrm{CO}_{2}, 60 \% \mathrm{H}_{2}$ and $28 \% \mathrm{~N}_{2}, v / v$ ); heterotrophic (in the presence of minerals and a $0.2 \%$ carbohydrate or a $0.1 \%$ organic acid); or on a nitrogen-free medium, in an atmosphere of $2 \% \mathrm{O}_{2}, 10 \% \mathrm{CO}_{2}, 10 \% \mathrm{H}_{2}$ and $78 \% \mathrm{~N}_{2}(v / v)$, or in an atmosphere of $2 \%$ $\mathrm{O}_{2}$ and $98 \% \mathrm{~N}_{2}(v / v)$. The growth of the microorganism on these media takes place at a temperature of $30^{\circ} \mathrm{C}$.

For the cultivation of the bacterium Alcaligenes latus DSM 1123, in 1988, Lafferty [85,86] described the following culture medium: sucrose $1.5 \mathrm{~g} \% ;\left(\mathrm{NH}_{4}\right)_{2} \mathrm{SO}_{4} 0.15 \mathrm{~g} \% ; \mathrm{Na}_{2} \mathrm{HPO}_{4} \cdot 2 \mathrm{H}_{2} \mathrm{O}$ $0.45 \mathrm{~g} \% ; \mathrm{KH}_{2} \mathrm{PO}_{4} 0.15 \mathrm{~g} \% ; \mathrm{MgSO}_{4} \cdot 7 \mathrm{H}_{2} \mathrm{O} 0.02 \% ; \mathrm{CaCl}_{2} \cdot 2 \mathrm{H}_{2} \mathrm{O} 0.002 \% ; \mathrm{Fe}$ III $\mathrm{NH}_{4}$ citrate $0.005 \mathrm{~g} \%$; $\mathrm{pH}$. The microelement solution had the following composition: $\mathrm{ZnSO}_{4} \cdot 7 \mathrm{H}_{2} \mathrm{O}$ $100 \mathrm{mg} / \mathrm{L} ; \mathrm{MnCl}_{2} \cdot 4 \mathrm{H}_{2} \mathrm{O} 30 \mathrm{mg} / \mathrm{L} ; \mathrm{H}_{3} \mathrm{BO}_{3} 300 \mathrm{mg} / \mathrm{L} ; \mathrm{CoCl}_{2} \cdot 6 \mathrm{H}_{2} \mathrm{O} 200 \mathrm{mg} / \mathrm{L} ; \mathrm{CuSO}_{4} \cdot 5 \mathrm{H}_{2} \mathrm{O}$ $10 \mathrm{mg} / \mathrm{L} ; \mathrm{NiCl}_{2} \cdot 6 \mathrm{H}_{2} \mathrm{O} 20 \mathrm{mg} / \mathrm{L} ; \mathrm{NaMoO}_{4} \cdot 2 \mathrm{H}_{2} \mathrm{O} 30 \mathrm{mg} / \mathrm{L}$; water $1 \mathrm{~L}$. In a continuous cultivation of three weeks carried out at $37{ }^{\circ} \mathrm{C}$, and maintaining $\mathrm{pH} 7$ throughout the cultivation, with this microorganism (Alcaligenes latus DSM 1123) and on this carbon source (sucrose $1.5 \mathrm{~g} \%$ ) a content of 71\% ... 79\% PHB compared to dry biomass was obtained.

Other precursors of the $3 \mathrm{HV}$ monomer include aliphatic fatty acids with a longer carbon chain length and an odd number of carbon atoms, such as valeric acid, heptanoic acid, and nonanoic acid, since the -oxidation cycle produces propionyl-CoA rather than acetyl-CoA [80]. Thus, the probability of obtaining polymer with a $3 \mathrm{HV}$ fraction is higher when fatty acids are present as a carbon source in the culture medium [86].

In the case of $\mathrm{mcl}$-PHA production, octanoic acid was used as the first carbon source, using Pseudomonas oleovorans as a microorganism [87]. As for scl-PHA, the type of substrate used for cell growth influences the biosynthesis path of mcl-PHA-producing bacteria. Thus, biopolymer production is closely related to the metabolic pathways of fatty acids $[59,88]$.

According to studies on the PHA product, the biopolymer yield and its physical and mechanical properties can be altered based on the carbon source and the composition of fermentation medium [89-91], influencing the scope of the resultant polymer [92]. In the cultivation of Pseudomonas oleovorans, for example, combinations of 5-phenylvaleric acid and n-alkanoic acids influenced the biopolymer composition and the yield of the bioprocess. Thus, the polymer content in 3-hydroxy-5-phenyl valerate increased for a higher addition of 5-phenylvaleric acid in the fermentation medium [93]. In another study, mcl-PHA with adapted olefinic monomer content was produced by P. putida GPo1 strain using different concentrations of octanoate and 10-undecenoate as a carbon source [92]. For Pseudomonas putida KT2442 growing in media with varying concentrations of octanoate and 6 (4-cyanophenoxy) hexanoate, mcl-PHA, composed of 3HO, 3HHX and 3-hydroxy-6 (4-cyanophenoxy) hexanoate, was produced [94].

\subsubsection{Fermentation Bioprocess}

For PHA biosynthesis, several microorganisms were studied using different operation modes of fermentation, namely: batch, fed-batch and continuous processes [48]. Batch fermentation is commonly employed in commercial fermentation processes due to its low overhead production costs. The cultivation approach is based on the addition of a carbon source to the culture medium at the start of the bioprocess and the accumulation of a biopolymer. Batch fermentation can be accomplished in two ways: one-stage cultivation and two-stage cultivation [95]. Cell development, synthesis, and biopolymer accumulation all occur at the same time in a single stage. The two-stage process contains two phases: microbial growth and biopolymer accumulation [96]. The culture is performed in the first stage to achieve a sufficient concentration of bacterial cells. In contrast, the bacterial growth 
rate remains constant in the second stage, the nutritional constraint stage, but the cells begin to deposit intracellular PHAs [97]. The batch fermentation procedure may also be associated with a low yield of polyhydroxyalkanoates due to PHA degradation after full utilization of the substrate, resulting in a low amount of the end product [98].

Batch fermentation was used to investigate mcl-PHA homopolymers synthesized by Pseudomonas species [99]. A strain of Pseudomonas mendocina, using sodium octanoate as a carbon source, produced biopolymers with a content of $31.38 \%$ of 3 -hydroxyoctanoate $[\mathrm{P}(3 \mathrm{HO})]$.

In batch culture operation, a mixture of carbon sources such as citrate/octanoate [48] or glucose/octanoic acid [97] can be used simultaneously to achieve cell growth and the production of $m c l$-Poly (3HA), the fatty acid acting as a structural precursor for the synthesis of mcl-Poly (3HA), and the structurally uncorrelated carbon source used to provide the energy support of bacterial cells. In this context, to produce mcl-PHA in batch mode, three strains of Pseudomonas, namely Pseudomonas fluorescens ICCF 392, Pseudomonas putida ICCF 391 and Pseudomonas aeruginosa ICCF 90, were also studied, using citric acid (glucose or glycerol) $2 \mathrm{~g} \%$ and/or octanoate or decanoate $0.25-0.5 \mathrm{~g} \%$, as carbon sources in a fermentation medium with mineral salts (medium E), with an initial pH of 7-7.2 in a bioprocess of $48 \mathrm{~h}$ at $30{ }^{\circ} \mathrm{C}$, on a rotary shaker [65]. It was found that each strain has a specific behavior towards the carbon source. Thus, the strain Pseudomonas putida ICCF 391 produced $1347 \mathrm{~g}$ mcl-PHA/L, when grown on medium E with glucose and octanoate, compared to Pseudomonas fluorescens ICCF 392, which produced a maximum of $1167 \mathrm{mcl}$ PHA / L and Pseudomonas aeruginosa ICCF 90 (ATCC 9027), which produced a maximum final concentration of $0.83 \mathrm{mcl}$-PHA/L. Tested on different media, they produced PHAs with C6:C8:C10:C11:C14 in different proportions; $\mathrm{C} 4$ and $\mathrm{C} 5$ monomers were not identified. The highest total content of $99.7 \%$ PHA, composed of $79 \%$ PHO and $6 \%$ PHD, was produced by P. fluorescens (Figure 3).

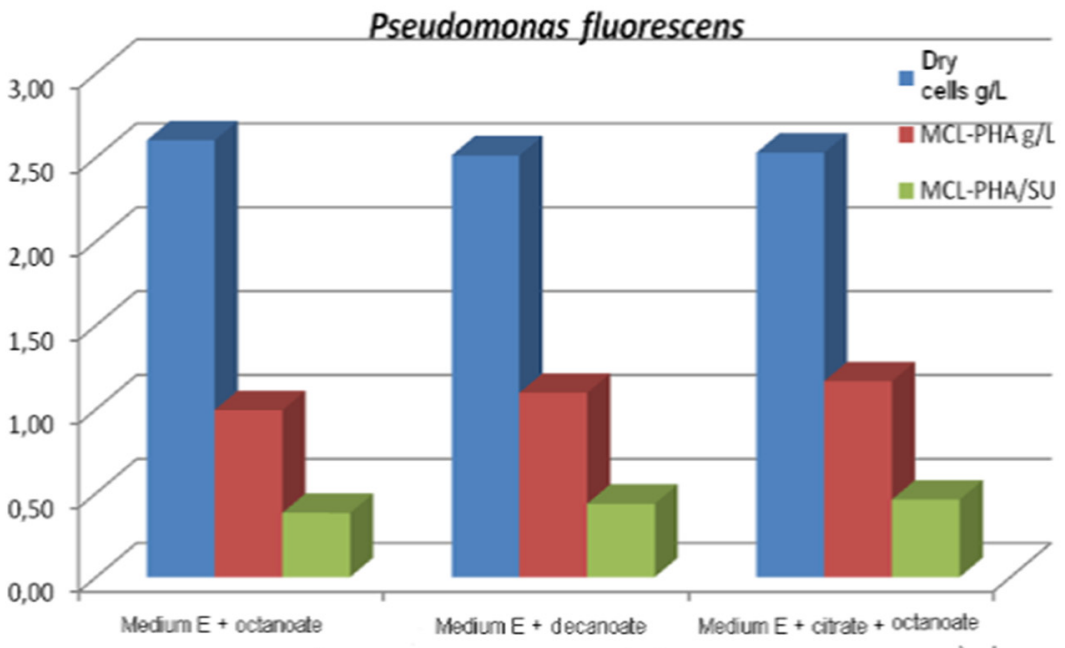

Figure 3. Biomass and $m c l$-PHA production Reprinted with permission from ref. [65], 2014, Vladu et al., Studia Universitatis.

For PHA production, the use of mixed cultures was introduced, improving fermentation efficiency [100]. The use of mixed open crops, such as activated sludge [101-103], can contribute to lowering the cost of PHAs, therefore increasing their market potential [104].

For the accumulation of poly-3-hydroxyoctanoate (PHO) [68], batch fermentation production was studied using a consortium of bacterial strains Pseudomonas putida and Bacillus subtilis / Bacillus subtilis BSV in a ratio of 3:1, compared to PHO biosynthesis with P. putida (Table 3, Figure 4). 
Table 3. Fed-batch fermentation for PHA biosynthesis. Reprinted with permission from ref. [68], 2016, Eremia et al., Ovidius Univ. Ann. Of Chem.

\begin{tabular}{|c|c|c|c|c|c|}
\hline \multirow{2}{*}{ No } & \multirow{2}{*}{ Strains } & \multirow{2}{*}{$\begin{array}{c}\mathrm{C} 8 \\
(\mathrm{~g} / \mathrm{L})\end{array}$} & \multicolumn{3}{|c|}{ Fermentation Final } \\
\hline & & & $\mathrm{pH}$ & $\mathrm{OD}^{1}$ & $D C^{2}(g / L)$ \\
\hline 1 & P.putida & 8.51 & 7.74 & 0.559 & 1.86 \\
\hline 2 & $\begin{array}{c}\text { P.putida:B.subtilis BSP } \\
(3: 1)\end{array}$ & 8.51 & 7.55 & 0.599 & 3.96 \\
\hline 3 & $\begin{array}{c}\text { P.putida:B.subtilis BSV } \\
(3: 1)\end{array}$ & 8.51 & 7.60 & 0.562 & 3.93 \\
\hline
\end{tabular}

${ }^{1}$ Optical Density measured at $550 \mathrm{~nm} .{ }^{2}$ Dry Cell Weight /L.

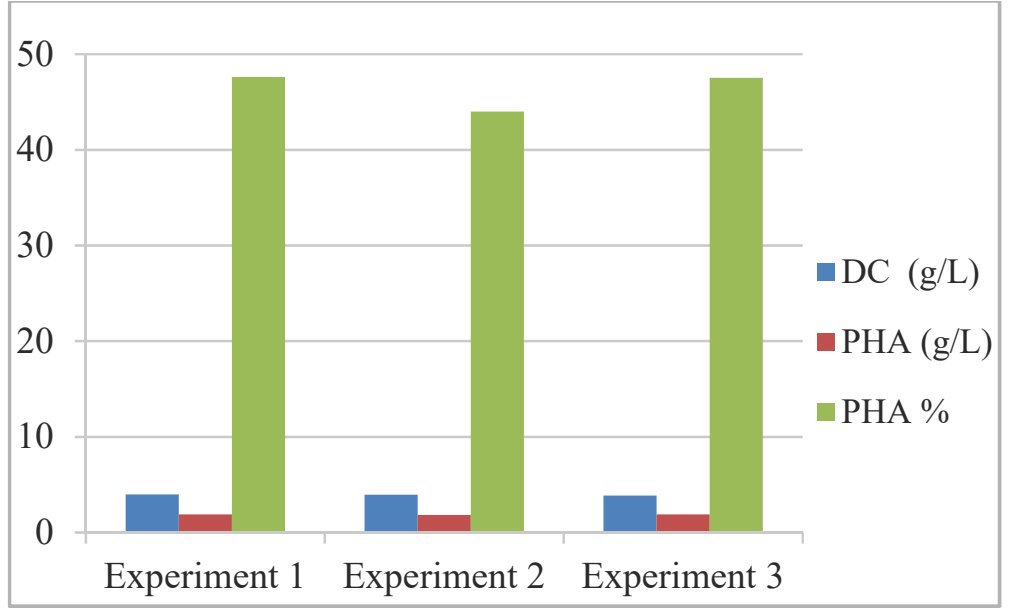

Figure 4. Biomass and mcl-PHA production with a consortium of microorganisms. Reprinted with permission from ref. [68], 2016, Eremia et al., Ovidius Univ. Ann. Of Chem.

The results revealed the consortium performance regarding the production of biopolymers (\%): 85.83-86.8 C8, 5.38-5.55 C6, and 5.65-6.45 C10 were obtained.

To obtain PHB with a strain of Alcaligenes latus, Grothe et al. [105] studied the process in fed-batch culture, with the bioprocess having the following characteristics: growth rate of $0.075 / \mathrm{h}$, sucrose consumption rate of $0.38 \mathrm{~g} / \mathrm{L}^{*} \mathrm{~h}$, with a maximum PHB rate of $0.15 \mathrm{~g} / \mathrm{L}^{*} \mathrm{~h}$. At the end of fermentation $(93 \mathrm{~h})$, under optimized conditions, the production yield of PHB was $60 \%$ of the dry cell mass.

In fed-batch cultivation, the fermentation process is more efficient than in the batch operation, because it reaches a high density of bacterial cells and the highest possible concentration of bioproduct $[106,107]$. During fermentation, the growth medium is supplemented with a portion of the substrate. This technique ensures consistent nutritional management, avoids carbon source restrictions, and allows for efficient microorganism growth and biopolymer buildup [107]. This culture method is ideal for the industrial production of PHA. In fed-batch culture, the strain Pseudomonas putida KT2440 can accumulate more mcl-PHA when co-substrates such as acrylic acid, nonanoic acid, and glucose are used. The authors showed that this fermentation synthesized 75.5\% PHA with $89 \mathrm{~mol} \%$ 3-hydroxynonanoate $(\mathrm{HN})$ at a feed mass ratio of nonanoic acid: glucose: acrylic acid of 1.25:1:0.05, and a specific growth rate of $0.15 \mathrm{~h}^{-1}$ [108].

In a study performed on P. putida strain KT2440 designed to synthesize mcl-PHA, with acetate as the only carbon source, $674 \mathrm{mg} / \mathrm{L}$ of $m c l$-PHA was produced in fed-batch culture, which was $92 \%$ higher than with the parent strain [109].

El-Sayed Azhar et al. [110] performed comparative studies on PHB production by Ralstonia eutropha strain ATCC 17697 and Alcaligenes latus ATCC 29712 grown on a productive medium as fed-batch. The data show that the weight of dry cell mass and sugar consumed increased during fermentation, resulting in a gradual increase in PHB concentration. The 
concentration and content of PHB obtained with sugar (glucose, sucrose) as carbon source by R. eutropha ATCC 17697 and A. latus ATCC 29712 were $10.53 \mathrm{~g} / \mathrm{L}$ and 64.52\% and $8.84 \mathrm{~g} / \mathrm{L}$ and 58, respectively, 12\%. Conversion coefficient, yield (\%), PHB biosynthesis rate and productivity were for R. eutropha ATCC $1769761.90 \%, 52.65 \%, 0.051 \mathrm{~g} / \mathrm{g} * \mathrm{~h}$ and $0.29 \mathrm{~g} / \mathrm{L}^{*} \mathrm{~h}$, and $46.81 \%, 41.40 \%, 0.050 \mathrm{~g} / \mathrm{g}^{*} \mathrm{~h}$ and $0.32 \mathrm{~g} / \mathrm{L}^{*} \mathrm{~h}$, for A. latus ATCC 29712, respectively.

Continuous culture is acknowledged as a practice that boosts productivity while also providing excellent consistency and uniformity of product quality, as well as the long-term genetic stability of the strain [111]. As soon as equilibrium conditions are reached, the active biomass concentration, PHA content, and substrates are constant. Under these conditions, cell harvesting is also ongoing [112]. The major disadvantage of this procedure is the risk of microbial infection, which might compromise entire batches of fermentation and result in large economic losses [113].

Pseudomonas putida GPo1 was used to perform the first continuous mcl-PHA biosynthesis [46]. The scientists confirmed that continuous culture was a viable method for providing bacterial cells with a sufficient substrate while preventing substrate concentrations in the culture medium from being inhibited. The percentage of PHA in the biomass remained constant at dilution rate of $0.24 / \mathrm{h}$ and an increasing carbon/nitrogen ratio (13\% of CDW). When the specific growth rate was shorter than $0.3 / \mathrm{h}$, the isolated PHAs had a steady proportion of monomer composition with a $3 \mathrm{HB} / 3 \mathrm{HHx} / 3 \mathrm{HO} / 3 \mathrm{HD}$ ratio of 0.1:1.7:20.7:1.0. By the strain Pseudomonas oleovorans ATCC 29347, grown on octane gas, mcl-PHA was produced in a continuous two-stage system. The specific growth rate of the microorganism in the first compartment was reached by connecting two bio-fermenters in series, resulting in PHA synthesis at higher rates in the second compartment. Pseudomonas oleovorans cells produced $63 \%$ PHA of CDW in the second fermenter, which was effluent under these conditions. The two-stage bioprocess is more efficient than a single-stage arrangement due to cell proliferation and mcl-PHA accumulation [114].

\section{Isolation and Purification}

The recovery of PHA from bacterial cells is a critical step in the successful manufacture of these polymers. This process entails extracting the polymer from the cells and purifying it after it has been recovered from the culture broth at the end of the manufacturing phase. The extraction methods are shown in Table 4. In the commercialization of PHA-based products, the cost of the process, as well as the purity of the recovered PHA, is critical [115]. PHA is generated intracellularly as carbon and energy storage macromolecules; therefore, its recovery requires cell lysis, which releases PHA granules, followed by solvent solubilization and PHA extraction from cell debris [116]. Selecting an appropriate extraction procedure is critical to the long-term sustainability of these plastic biopolymers [117,118].

PHA can be extracted from microbial biomass by solvent extraction or chemical digestion of non-PHA cell mass (NPCM). Both procedures capture bacterial cells by filtering the culture broth or centrifuging the supernatant, which no longer contains cells. The PHA polymer is extracted from the biomass that remains in the pellet [119]. Mixed procedures are also used, for example, the isolation of PHA occurring after chemical or enzymatic digestion of biomass, or after a chemical technique. The disintegration, deslipidization, and anhydrization of PHA are followed by both procedures. The insoluble substance is then extracted as PHA using a solvent such as chloroform or acetone [66]. In Figure 5, a possible post-biosynthesis processing flow of a PHA polymer, using solvent extraction, is presented. 


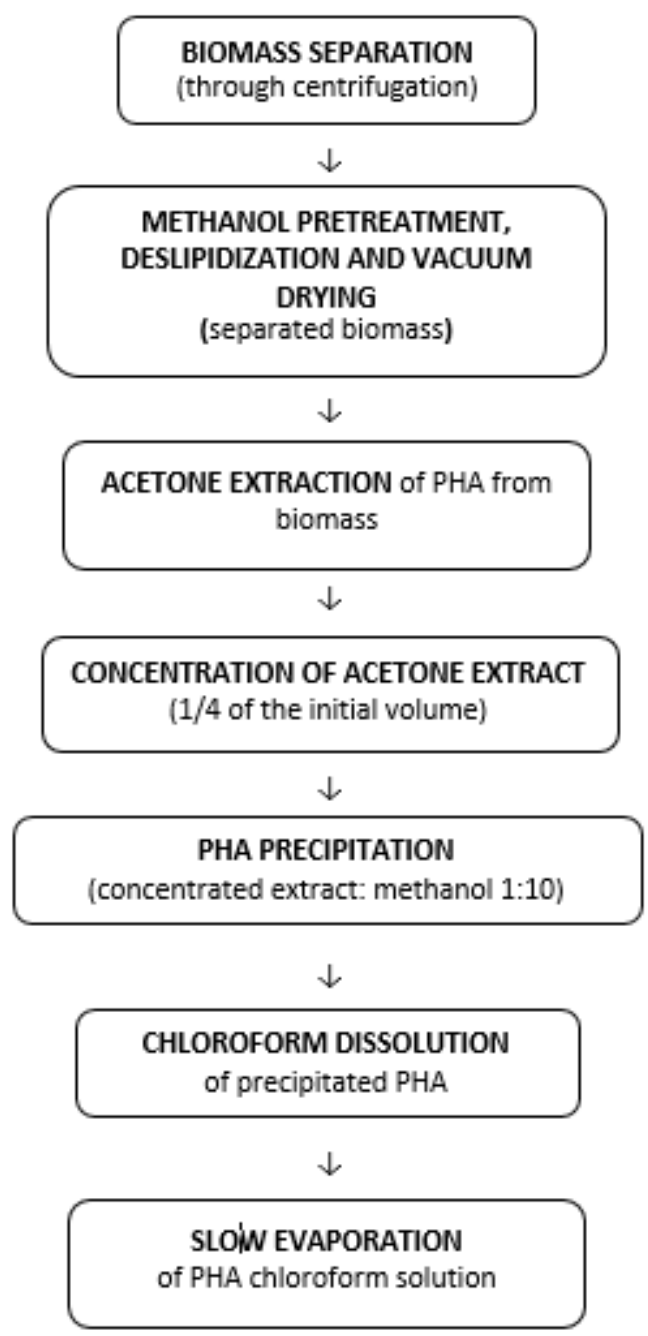

Figure 5. Post-biosynthesis processing flow of a PHA. Reprinted with permission from ref. [66], 2016, Lupescu et al., Rev.Chim.

\subsection{Solvent Extraction}

Solvent extraction is the PHA extracting process from biomass by dissolving it in an organic solvent (see Table 4). Chloroform, methyl ether, methylene chloride, or nonchlorinated solvents can all be used [120,121]. PHAs are recovered from dry biomass using an organic solvent and/or heating, as well as Soxhlet extraction. Soxhlet extraction is a simple and efficient technique in which PHA-containing biomass is exposed to a solvent such as chloroform or acetone [66,71], which changes the cell membrane and allows for the release of PHA granules and polymer solubilization [122]. To eliminate cellular debris, the solution is filtered or centrifuged. The solvent is then evaporated, leaving an impure biopolymer with cellular components that are soluble in the organic solvent [66].

\subsection{Digestion of Non-PHA Cell Mass (NPCM)}

Physical treatments, such as mechanical disintegration in ball mills, heat or ultrasound treatment, or chemical treatments such as surfactants, alkalis or acids, and enzymatic treatments, are used in NPCM digestion [117]. Following the chosen treatment, the PHA granules are separated from the cellular components using filtration or centrifugation. To reach as high a biomaterial purity as possible, the steps must be repeated numerous times [123]. As it does not utilize chemicals, the treatment process for bead mills is environmentally friendly. It has an expandable capacity, but it takes a long time to process and usually requires several steps [124]. To optimize PHA extraction and purity yield, this can 
be combined with other chemical or enzymatic treatments. This approach, for example, extracts P (3HB) from Alcaligenes latus [125].

Chemical digestion with sodium hypochlorite (see Table 4), which solubilizes all cellular debris while leaving the biopolymer granules intact, is a well-known technique for PHB extraction in microbial cultures [126]. PHB from Cupriavidus necator, for example, was extracted using this approach and biomass was recovered at a rate of over $90 \%$ with a purity of up to $98 \%$ [127]. This process, however, has a number of disadvantages, including the use of sodium hypochlorite, which lowers the molecular weight of the final biopolymer and leaves residues that are difficult to remove from the PHA [128]. In the preparation of $\mathrm{mcl}$ PHA, enzymatic approaches are expensive technologies with complex processes [120]. A combination of enzymes containing alkalase, SDS, ethylenediaminetetraacetic acid (EDTA), and lysozyme were employed to digest P. putida NPCM for mcl-PHA extraction (see Table 4). This technique yielded a $90 \%$ polymer recovery rate and a $92.6 \%$ purity rate [129]. The advantage of this method is that it has been demonstrated to be an environmentally friendly extraction procedure with a negative impact on the biopolymer's final molecular weight, but the method is costly due to the huge number of steps required to obtain as pure a polymer as possible [126].

Table 4. PHAs extraction methods.

\begin{tabular}{|c|c|c|c|c|}
\hline Method & Chemical & Conditions & Purity and Recovery & Reference \\
\hline \multirow{5}{*}{$\begin{array}{c}\text { Solvent } \\
\text { extraction }\end{array}$} & Chloroform & Mixing continuously at $25^{\circ} \mathrm{C}$ for $12 \mathrm{~h}$ & $\begin{array}{l}\text { Purity: } 94.0-96.0 \% \\
\text { Recovery: } 65-70 \%\end{array}$ & [130] \\
\hline & Methylene chloride & Mixing continuously t $25^{\circ} \mathrm{C}$ for $12 \mathrm{~h}$ & $\begin{array}{c}\text { Purity: } 95-98 \% \\
\text { Recovery: } 24-25 \%\end{array}$ & [130] \\
\hline & 1,2-Dichloroethane & Mixing continuously at $25^{\circ} \mathrm{C}$ for $12 \mathrm{~h}$ & $\begin{array}{c}\text { Purity: } 93-98 \% \\
\text { Recovery: } 66-70 \%\end{array}$ & [130] \\
\hline & Acetone & $\begin{array}{l}\text { Continuous mixing at } 120^{\circ} \mathrm{C}, 7 \text { bar for } 20 \mathrm{~min} \\
\text { under anaerobic conditions, followed by } \\
\text { filtering hot solution and cooling it to } 4{ }^{\circ} \mathrm{C} \text { to } \\
\text { precipitate polymer }\end{array}$ & $\begin{array}{c}\text { Purity: } 98.4 \% \\
\text { Recovery: } 96.8 \%\end{array}$ & [129] \\
\hline & $\begin{array}{l}\text { Medium-chain-length } \\
\text { alcohols }\end{array}$ & $\begin{array}{l}\text { In continuous stirred tank reactors, a } \\
\text { multi-stage extraction technique is used. Cool } \\
\text { the extract to recover the polymer after } \\
\text { removing the cell debris }\end{array}$ & $\begin{array}{c}\text { Purity: }>98.0 \% \\
\text { Recovery: } 95.0 \%\end{array}$ & [131] \\
\hline \multirow{2}{*}{$\begin{array}{l}\text { Hypochlorite } \\
\text { digestion }\end{array}$} & Sodium hypochlorite & $\begin{array}{l}\text { Biomass concentration: } 10-40 \mathrm{~g} / \mathrm{L} \text {; } \mathrm{pH}: 8-13.6 \text {; } \\
\text { Temperature: } 0-25^{\circ} \mathrm{C} \text {; Digestion time: } 10 \\
\text { min-6 h; Hypochlorite concentration: } 1-10.5 \% \\
\text { weight/volume }(w / v)\end{array}$ & $\begin{array}{l}\text { Purity: } 90-98.0 \% \\
\text { Recovery: } 90-95 \%\end{array}$ & [132] \\
\hline & $\begin{array}{l}\text { Sodium hypochlorite } \\
\text { and chloroform }\end{array}$ & $\begin{array}{l}\text { Biomass concentration: } 1 \%(w / v) \text {; } \\
\text { Temperature: } 30^{\circ} \mathrm{C} \text {; Digestion time: } 1 \mathrm{~h} \text {; } \\
\text { Hypochlorite concentration: } 3-20 \%(v / v)\end{array}$ & $\begin{array}{l}\text { Purity: } 86.0 \% \\
\text { Recovery: NG } \\
\text { Purity: } 93.0 \% \\
\text { Recovery: NG }\end{array}$ & [133] \\
\hline $\begin{array}{l}\text { Enzyme } \\
\text { digestion }\end{array}$ & $\begin{array}{l}\text { Trypsin, bromelain, } \\
\text { pancreatin }\end{array}$ & $\begin{array}{l}\text { Digestion with } 2 \% \text { trypsin }\left(50{ }^{\circ} \mathrm{C}, \mathrm{pH} 9.0,1 \mathrm{~h}\right) \\
\text { or } 2 \% \text { bromelain }\left(50^{\circ} \mathrm{C}, \mathrm{pH} 4.75,10 \mathrm{~h}\right) \text { or } 2 \% \\
\text { pancreatin }\left(50^{\circ} \mathrm{C}, \mathrm{pH} 8.0,8 \mathrm{~h}\right) \text {, followed by } \\
\text { centrifugation then washing with } 0.85 \% \\
\text { saline solution }\end{array}$ & $\begin{array}{l}\text { Purity: 87.7-90.3\% } \\
\text { Recovery: NG }\end{array}$ & [134] \\
\hline
\end{tabular}

\subsection{Purification of PHA}

PHA in medical and pharmaceutical applications should have high purity, especially for tissue engineering, with no contaminants such as surfactants or endotoxins [135]. Biologically active contaminants, such as proteins and lipopolysaccharides, must also be eliminated since they can trigger immunological reactions. Lipopolysaccharides, which 
are found in bacteria's membrane and are released after cell lysis, can contaminate the polymer and act as endotoxins [125]. When the polymer comes into contact with blood, it can cause negative responses [119]. Dissolution, precipitation, and washing with methanol or ethanol are the most common methods for purifying PHA. However, their use raises the overall cost of purification, implying an increase in the cost of producing PHA on a large scale [136].

Another method of purification is hydrogen peroxide treatment in conjunction with the action of enzymes or chelating agents. This begins by processing the cell suspension containing PHA, which is heat-treated, followed by enzymatic hydrolysis, sulfate treatments, and the final discoloration with hydrogen peroxides. All these steps lead to high costs, even though the use of enzymes leads to good recovery results [137]. Following studies of enzymatic hydrolysis, the best results $(88.8 \%$ P3HB purity) were obtained with $2 \%$ bromelain (enzyme mass per biomass) at $50{ }^{\circ} \mathrm{C}$ and $\mathrm{pH} 9.0$. Good results (90\% purity) were also obtained with a pancreatin that is three times cheaper than bromelain [134]. On Burkholderia sp. PT19, a combination approach incorporating enzymes and sodium hypochlorite was used [138]. Using papain, a purity of $89 \%$ was obtained. Yasotha et al. [139] investigated another combined method involving the use of alkalis, SDS, and EDTA, succeeding in the culture of $P$. putida to obtain by extraction $71.55 \%$ PHA, which was recovered in a water suspension by removing solubilized non-PHA cell material by ultrafiltration and purification in a continuous diafiltration process. Finally, a PHA with a purity of $92.6 \%$ was produced [139].

In 2001, Horowitz and Brennan proposed the use of ozone to purify PHA, where ozone was applied to biomass in an oxygen stream containing between 2 and 5\% ozone. Ozone treatment facilitates the removal of impurities by solubilizing, bleaching and deodorizing aqueous polymer suspensions. This method is advantageous compared to the treatment of PHA with hydrogen peroxide, and disadvantageous due to its high temperature, peroxide instability in the presence of a high cell biomass and decreased molecular weight of the polymer [140].

\section{Characterization, Methods and Results}

Purified PHA polymers have different chemical compositions and properties due to various monomer units and the different insertions of these monomers in other polymer chains. Therefore, to identify a suitable application of a PHA polymer, it is necessary to characterize the biomaterial through different specific techniques, as seen in Table 5.

Table 5. Techniques for PHA polymer characterization.

\begin{tabular}{|c|c|c|c|}
\hline Characteristics & Method & Typical Conditions & Reference \\
\hline \multirow[b]{2}{*}{$\begin{array}{l}\text { PHA monomeric } \\
\text { composition }\end{array}$} & Gas chromatography (GC) & $\begin{array}{l}\text { In GC-FID analysis, a BP-20 polar capillary column was } \\
\text { used. This column or an HP-5MS capillary column could } \\
\text { be used in GS-MS chromatography. }\end{array}$ & {$[141,142]$} \\
\hline & Liquid chromatography (LC) & $\begin{array}{l}\text { A UV detector at } 210 \mathrm{~nm} \text { and an ion-exclusion organic } \\
\text { acid analysis column are used in high-performance liquid } \\
\text { chromatography. } \\
\text { For HPLC-MS analysis, a C18 column is used for } \\
\text { separation. The source parameters are optimized to obtain } \\
\text { the dominant ions for all compounds and keep them } \\
\text { constant throughout the analysis. }\end{array}$ & {$[143,144]$} \\
\hline
\end{tabular}


Table 5. Cont.

\begin{tabular}{|c|c|c|c|}
\hline Characteristics & Method & Typical Conditions & Reference \\
\hline $\begin{array}{l}\text { PHA polymeric } \\
\text { composition }\end{array}$ & $\begin{array}{l}\text { Nuclear magnetic resonance } \\
\text { (NMR) }\end{array}$ & $\begin{array}{l}\text { Chemical changes were expressed in ppm relative to the } \\
\text { remaining chloroform signals as an internal reference }(1 \mathrm{H} \\
\text { NMR: } 7.26 \text { ppm; } 13 \mathrm{C} \text { NMR: } 77.0 \mathrm{ppm}) \text {. } \\
\text { At } 499.883 \mathrm{MHz} \text {, a } 1 \mathrm{H} \text { NMR spectrum was acquired using } \\
\text { the following parameters: } 6.7 \mathrm{~s} 90^{\circ} \text { pulse duration, } \\
4112 \mathrm{~Hz} \text { spectral width, } 64 \mathrm{k} \text { data points, } 24 \text { scans, and a } \\
\text { relaxation delay of } 20 \mathrm{~s} \text {. } \\
\text { 13C NMR spectrum was recorded at } 125.709 \mathrm{MHz} \text { with } \\
1 \mathrm{H} \text { WALTZ decoupling. } \\
\text { Other parameters were chosen as follows: } 6.45 \mathrm{~s} 45^{\circ} \text { pulse } \\
\text { length, } 25,510 \mathrm{~Hz} \text { spectral width, } 64 \mathrm{k} \text { datapoints, } \\
24,000 \text { scans, relaxation delay } 10 \mathrm{~s} \text {, and decoupling } \\
\text { field } 2.5 \mathrm{kHz}\end{array}$ & {$[145]$} \\
\hline
\end{tabular}

Matrix assisted laser desorption ionization-time of flight-mass spectrometry (MALDI-TOF-MS)

The MALDI-TOF mass spectra is using a delay extraction procedure with ion detection in linear mode: $25 \mathrm{kV}$ applied after $2600 \mathrm{~ns}$ with a potential gradient of 454 $\mathrm{V} / \mathrm{mm}$ and a wire voltage of $25 \mathrm{~V}$.

The laser irradiation was slightly above the threshold to prevent polymer fragmentation: $106 \mathrm{~W} / \mathrm{cm}^{2}$, and each spectrum can have an average of 32 laser pulses.

Samples were diluted to a concentration of $0.5 \mathrm{mg} / \mathrm{mL}$ in chloroform and placed in an orbital shaker for $16 \mathrm{~h}$.

Molecular Gel permeation distribution chromatography (GPC)

To facilitate dissolution, samples were heated to $60^{\circ} \mathrm{C}$ for $5 \mathrm{~min}$, when necessary.

HPLC-grade chloroform was used as the mobile phase, and samples were processed at a flow rate of $1 \mathrm{~mL} / \mathrm{min}$. The detector temperature was set to $45^{\circ} \mathrm{C}$.

The samples were evaluated under dry nitrogen. 6-8 mg samples were enclosed in hermetic aluminum pans, equilibrated at $70^{\circ} \mathrm{C}$, and held isothermally for $5 \mathrm{~min}$. They were then heated to $100^{\circ} \mathrm{C}$ at a rate of

Differential scanning calorimetry (DSC)

Thermal properties
$5{ }^{\circ} \mathrm{C} / \mathrm{min}$, kept isothermally for $3 \mathrm{~min}$, and then cooled to

$70{ }^{\circ} \mathrm{C}$ at a rate of $5{ }^{\circ} \mathrm{C} / \mathrm{min}$. Finally, the samples were reheated to $100{ }^{\circ} \mathrm{C}$ at a rate of $5^{\circ} \mathrm{C} / \mathrm{min}$. While calculating the percentage crystallinity, the fusion heat on cold crystallization was calculated using the heat flux of melting from the second heat cycle.
Thermogravimetric analysis (TGA)
A sample was placed on platinum pan for each analysis. A nitrogen atmosphere was used at, $50 \mathrm{~mL} / \mathrm{min}$, for analysis.

Furnace temperature was set from $0{ }^{\circ} \mathrm{C}$ to $800{ }^{\circ} \mathrm{C}$ at a heating ramp of $10^{\circ} \mathrm{C} / \mathrm{min}$. Temperature accuracy can be maintained $\pm 0.25{ }^{\circ} \mathrm{C}$
The samples are a mixt of $5 \mathrm{mg}$ PHA with $100 \mathrm{mg}$ of $\mathrm{KBr}$ and pelletized. The infrared spectra were obtained in the 4000 to $400 \mathrm{~cm}^{-1}$ wavenumber range.

Sample was melt at $100{ }^{\circ} \mathrm{C}$ for $2 \mathrm{~min}$ in FTIR hot stage under the protection of dry nitrogen gas. The amorphous sample was then quenched to selected temperature by a flow of liquid nitrogen for isothermal melt-crystallization.

Crystallinity

Fourier transform infrared spectroscopy (FTIR)
Afterward, the isothermally crystallized samples were heated again at $1^{\circ} \mathrm{C} / \mathrm{min}$.

The samples were size of $10 \mathrm{~mm} \times 10 \mathrm{~mm}$ for testing. The diffractometer with $\mathrm{Cu}-\mathrm{K} \alpha$ radiation, wavelength = X-ray diffraction
$1.542 \AA$, scanning from $10^{\circ}$ to $50^{\circ}$ in $2 \theta$ at a scanning speed of $10^{\circ} / \mathrm{min}$ 
Table 5. Cont.

\begin{tabular}{|c|c|c|c|}
\hline Characteristics & Method & Typical Conditions & Reference \\
\hline $\begin{array}{l}\text { Mechanical } \\
\text { properties }\end{array}$ & Mechanical testing machine & $\begin{array}{c}\text { Film strips: } 135 \mathrm{~mm} \times 22 \mathrm{~mm} \text {, were tested with static load } \\
\text { cell; maximum load of } 5 \mathrm{KN} \text { (Rating }= \pm 50 \mathrm{~N} \text {; Max Torque } \\
= \pm 1.5 \mathrm{~N} \mathrm{~m} \text { ) for a temperature range of }-29 \text { to } 82{ }^{\circ} \mathrm{C} \text { was } \\
\text { used. A } 125 \mathrm{~mm} \text { initial gap separation and a separation } \\
\text { rate of } 12.5 \mathrm{~mm} \min ^{-1} \text { were used for tensile testing at } \\
\text { room temperature. }\end{array}$ & {$[153]$} \\
\hline
\end{tabular}

\subsection{Monomeric Composition and Molecular Distribution}

Many analytical methods for PHA detection can provide quantitative information about PHAs. For example, the monomeric composition and distribution of PHA can be determined by various methods, such as high-performance liquid chromatography [144], gas chromatography [154] or nuclear magnetic resonance spectroscopy (NMR) [155]. However, the ability to provide qualitative information about monomeric constituents is limited to LC. Solvent extraction is a time-consuming step in the sample preparation process for GC analysis. In contrast to GC-MS, liquid chromatography-mass spectrometry (LC-MS) allows for the measurement of known PHA monomers upon hydrolysis without the need for solvent extraction [156]. However, NMR and GC methods can provide qualitative and quantitative information on PHA. Therefore, GC-based methods are most often used against NMR due to the ease of sample preparation and lower costs [142]. GC coupled with flame ionization detector (GC-FID) is one of the most commonly used methods to identify and quantify PHAs. However, GC-FID largely depends on the inclusion of appropriate PHA analytical standards [157]. Due to the lack of chemicals in sample preparation, and the precision and accuracy with which PHA structures are detected, matrix-assisted laser desorption ionization time-of-flight mass spectrometry (MALDI-TOF-MS) is far superior to other approaches to identifying monomeric composition. In addition, this method can also be used in the molecular weight assessment and molecular weight distribution of PHA [158].

With good sensitivity, linearity, accuracy, and reproducibility, the suggested innovative LC-MS approach permitted the simultaneous measurement of seven PHA monomer standards utilizing IAA (Indole-3-acetic acid) as an internal standard in a single chromatographic run. With MS-guided fractionation, the LC technique was also able to effectively isolate unknown PHA monomers. If the isolated unknown PHA monomers are pure enough, then NMR spectroscopy can reveal their structure. The combination of LC and NMR enabled the structural characterization of a wide range of unusual PHA monomers [143]. The monomeric composition of PHAs was determined using an improved LC-MS method. PHAs were extracted from Pseudomonas cultures on various carbon sources and utilized as actual samples to demonstrate the analysis and detection of PHA monomers, as shown in Figure 6A-C. According to Figure 6B,C, the PHAs were made up of three unknown PHA monomers called Unk1, Unk2, and Unk3, in addition to C6, C8, C10, C12, C14, and C16. The molecular masses of Unk1, Unk2, and Unk3 were determined using MS spectra to be 214,242 , and 270 , respectively. The presence of potential PHA monomers was deduced based on their molecular weights to be monounsaturated monomers: 3-hydroxydodecenoic acid (C12:1), 3-hydroxytetradecenoic acid (C14:1), and 3-hydroxyhexadecenoic acid (C16:1) [143].

A gel permeation chromatography (GPC) system calibrated to standards can estimate molecular mass and molecular dispersion. However, molecular mass determination analysis of a PHA can become complicated, especially when the polymer is a combination of several PHAs, so more than two connected GPC columns are required to determine the molecular weight and distribution [147]. 

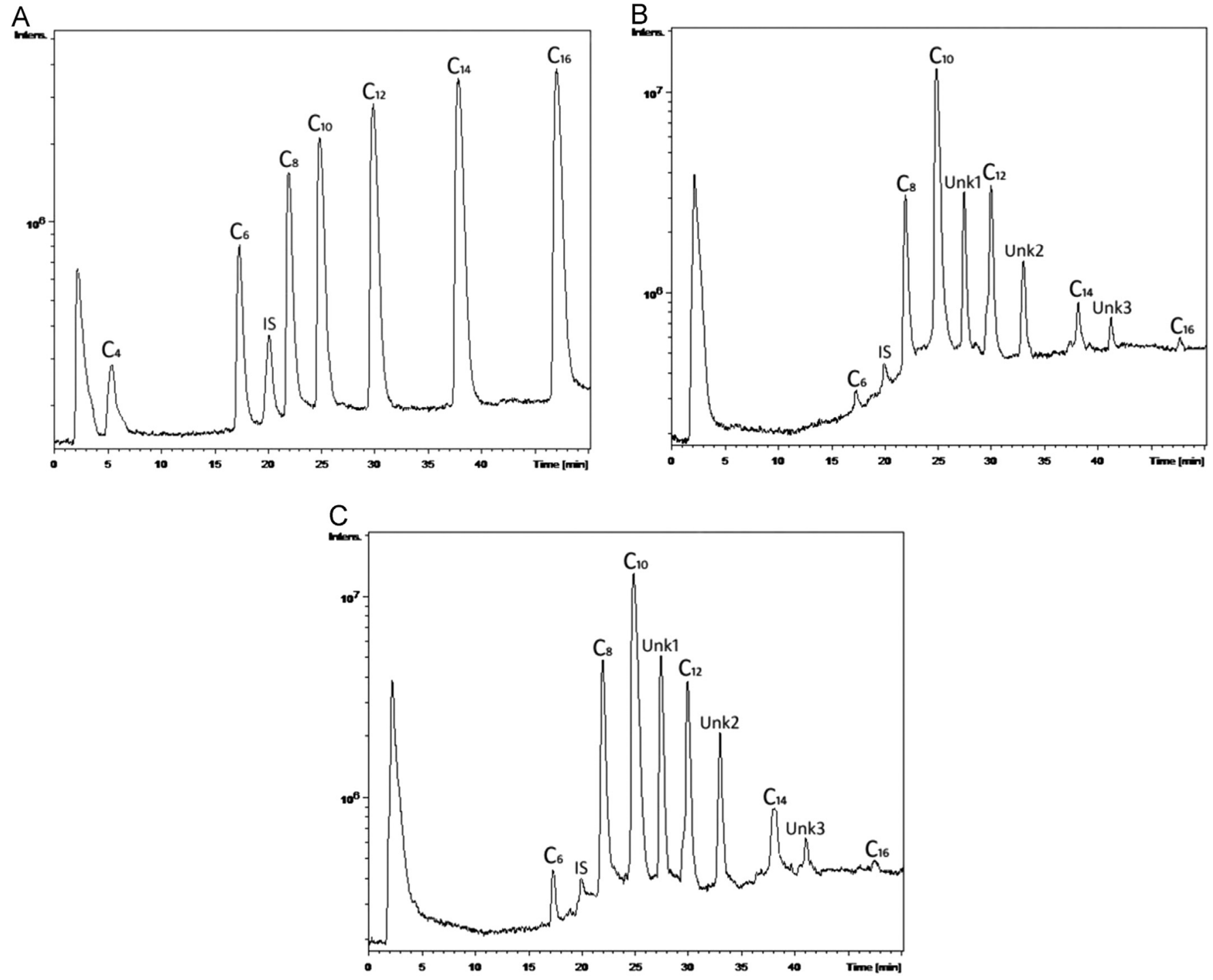

Figure 6. Typical LC-MS total ion chromatograms of (A) PHA monomer standards with concentration of $1.0 \mathrm{mg} \mathrm{mL}^{-1} \mathrm{C} 4,0.5 \mathrm{mg} \mathrm{mL}^{-1} \mathrm{C} 6,0.25 \mathrm{mg} \mathrm{mL}^{-1} \mathrm{C} 8, \mathrm{C} 10, \mathrm{C} 12, \mathrm{C} 14$ and C16, and $0.1 \mathrm{mg} \mathrm{mL}^{-1}$ IAA; (B) PHA monomers in the polymer extracted from P. putida NBUS12 after hydrolysis; and (C) PHA monomers in the polymer extracted from Pseudomonas sp. TAPHA2 after hydrolysis. Reprinted with permission from ref. [143], 2016, Ge et al., Elsevier.

\subsection{Thermal Properties}

Using the PHA polymer requires to determine the temperature conditions such as thermal properties, melting temperatures, and degradation temperatures. The known melting temperature of a standard PHA is $177^{\circ} \mathrm{C}$, and, for a copolymer, this is generally lower than the homopolymer temperature, at about $143^{\circ} \mathrm{C}$. By DSC analysis, the most-used thermal method, we can determine both qualitative and quantitative results because of the thermal data of the polymer. Thus, the endothermic peak may indicate a maximum of $115{ }^{\circ} \mathrm{C}$, representing the loss of absorbed water, and the exothermic peak between $175^{\circ} \mathrm{C}$ and $350^{\circ} \mathrm{C}$ could show subsequent recrystallization. All this indicates the high stability of the polyester [159].

The thermal behavior of mcl-PHA polymers is shown in Figure 7a-c. The DSC diagrams reveal that the monomer composition has a significant impact on thermal behavior. Melting temperatures range from $50{ }^{\circ} \mathrm{C}$ to $54{ }^{\circ} \mathrm{C}$, with melting enthalpies ranging from $11 \mathrm{~J} / \mathrm{g}$ to $15 \mathrm{~J} / \mathrm{g}$, indicating a low degree of crystallinity. According to the diagrams included in Figure 8, the melting behavior is influenced by the hexanoate concentration, with lower 
C6 fractions of PHAs being associated with lower melting temperatures [66]. In addition, Figure 7c shows DSC thermograms of both polymers by comparison ( $m c l$-PHA obtained in laboratory and commercial scl-PHA) with differing thermal behaviors. The melting temperature of $m c l$-PHA is significantly lower than that of $s c l$-PHA, $53^{\circ} \mathrm{C}$ instead of $169^{\circ} \mathrm{C}$. Due to the increased length of the $\mathrm{CH}_{2}$ chain in their structure, which obstructs hydrogen bonding, $m c l$-PHA acts as a thermoplastic elastomer, with higher chain mobility and a lower melting temperature. Moreover, $m c l$-PHA has a greater amorphous/crystalline phase ratio and, therefore, a lower melting enthalpy: $14 \mathrm{~J} / \mathrm{g}$ rather than $56 \mathrm{~J} / \mathrm{g}$ [66].
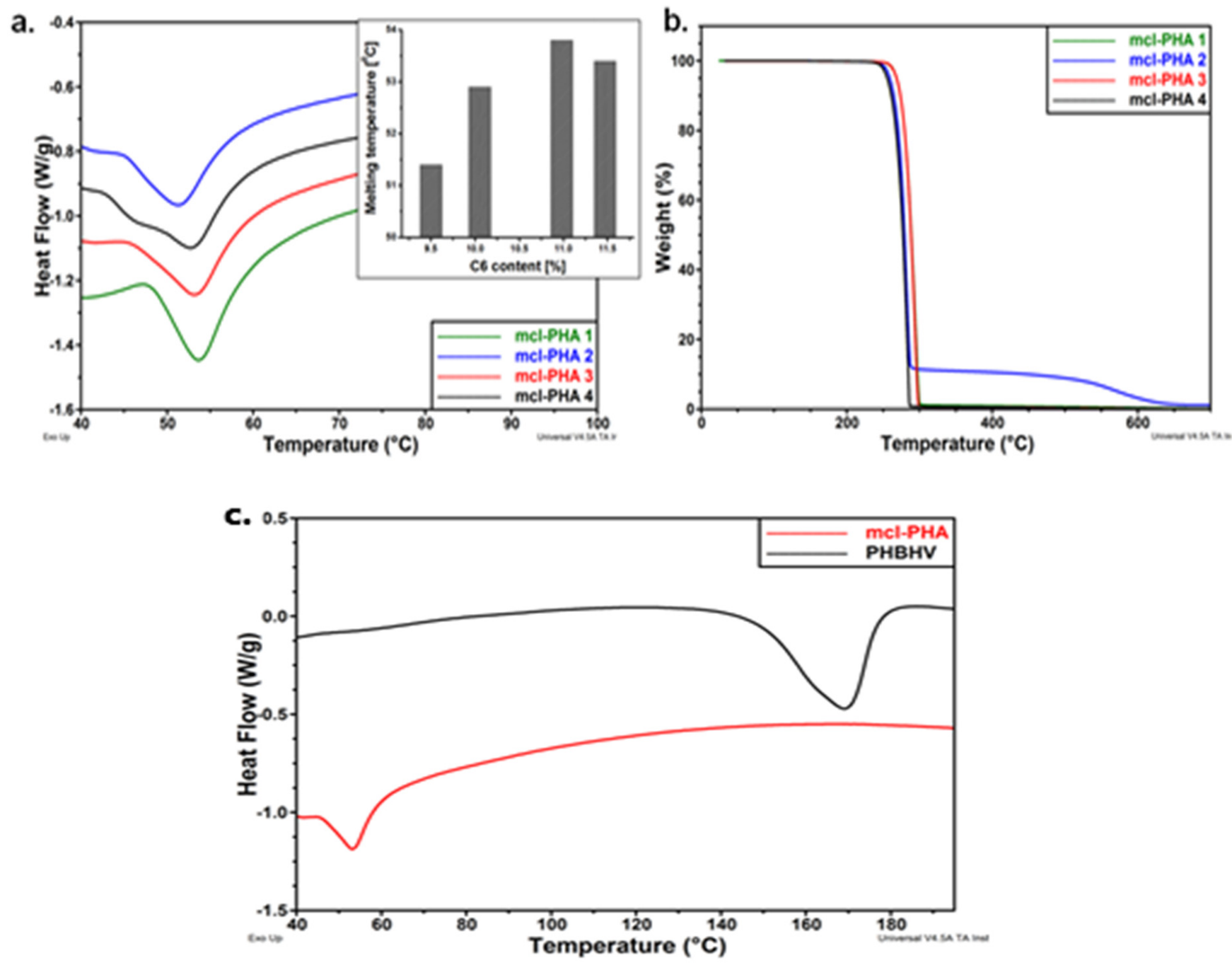

Figure 7. (a) DSC thermograms of $m c l$-PHAs (inset: melting temperature vs. C6 content in PHAs); (b) TGA curves of mcl-PHAs (c) DSC thermograms of mcl-PHAs and PHBHV. Reprinted with permission from ref. [66], 2016, Lupescu et al., Rev.Chim.

TGA can determine degradation temperature, and the sample is heated in a controlled atmosphere to a point, while the mass loss of the polymer is measured [154]. Figure $7 \mathrm{~b}$ shows the TGA curves for the tested mcl-PHA polymers, which indicates a one- or two-step degradation process. For all samples, the degradation temperature is higher than $270{ }^{\circ} \mathrm{C}$. The samples with a higher $\mathrm{C} 6$ concentration ( $m c l$-PHA 1 and mcl-PHA 3) show a higher degradation temperature at the beginning (at $279{ }^{\circ} \mathrm{C}$ and $280^{\circ} \mathrm{C}$, respectively), indicating a better thermal behavior than those with a lower $\mathrm{C} 6$ concentration ( $m c \mathrm{cl}$-PHA 2 and $m c l$-PHA 4) [66]. 




Figure 8. FTIR spectra of mcl-PHAs and PHBHV. Reprinted with permission from ref. [66], 2016, Lupescu et al., Rev.Chim.

\subsection{Crystallinity}

The crystallinity of the polymer can be determined by structural analysis using FTIR or $\mathrm{X}$-ray diffraction. FTIR determines the infrared absorption wavebands, which are correlated with the crystallinity of the material. Due to the different chemical composition of the polymer, those bands do not have a fixed location. The bands between 1279 and $1185 \mathrm{~cm}^{-1}$ are representative of $s c l$-PHA and fall between 1500 and $800 \mathrm{~cm}^{-1}$, indicating the that changes occurred both in the crystalline phase and the amorphous phase for mcl-PHA and scl-mcl-PHA [160,161].

For example, Figure 8 shows the FTIR spectrum of a mcl-PHA polymer film compared to a commercial scl-PHA (PHBHV). As mcl-PHA is still produced in the laboratory, its structure is determined by comparing it to a PHA with established features. Following analysis, it was discovered that PHBHV has absorbance peaks between $2975 \mathrm{~cm}^{-1}$ and $2932 \mathrm{~cm}^{-1}$, which correspond to asymmetric and symmetrical stretching of the $\mathrm{CH}_{3}$ vibration, a robust stretching vibration of $\mathrm{C}=\mathrm{O}$ at $1720 \mathrm{~cm}^{-1}$, and wavelengths between $1280 \mathrm{~cm}^{-1}$ and $1060 \mathrm{~cm}^{-1}$, which correspond to C-O-C stretching vibrations. The essential diagnostic peaks $\mathrm{CH}_{3}$ and $\mathrm{C}=\mathrm{O}$, on the other hand, appear in $m c l-\mathrm{PHA}$, although with a slightly modified intensity and displacement. The wavelength of $\mathrm{CH}_{3}$ is measured between 2957 and $2931 \mathrm{~cm}^{-1}$, while $\mathrm{C}=\mathrm{O}$ has a higher intensity of $1725 \mathrm{~cm}^{-1}$. These observations could indicate that both polymers have different amorphous/crystalline phase ratios. In addition, the increased length of the $\mathrm{CH}_{2}$ chain in mcl-PHA may explain the higher strength of the intense vibrations for the $\mathrm{C}-\mathrm{H}$ group compared to scl-PHA [66].

$\mathrm{X}$-ray diffraction also determines the crystallinity rate of the polymer, the chemical bonds and the disorder of the atoms [152].

\subsection{Mechanical Properties}

The suitable mechanical properties of polymers as scaffolds in tissue engineering depend on the mechanical characteristics of the natural tissue that they should substitute. The natural skin, for example, has tensile strength values ranging from 5.0 to $30.0 \mathrm{MPa}$, Young's modulus values between 4.6 and $20.0 \mathrm{MPa}$, and skin elongation at break values with the approximate range $35.0-115.0 \%$. As a result, a high mechanical stress is required to assure the durability of specific natural structures generated in the skin substitute [162]. Another example may be the required qualities of a tracheal cartilage wall, which should be robust enough to keep the airway open (high elongation at break), but flexible enough to allow flexion during breathing cycles due to intrathoracic pressure variations (high tensile strength and Young modulus) [163]. The PHA polymer may be a soft elastomeric 
material such as mcl-PHA or a rigid material such as scl-PHA. The elongation of a material is determined by measuring its extent until it breaks. In addition, the tensile strength is determined by applying a pulling force until the material breaks [164]. The mechanical strength of PHA-type biopolymers is influenced by the carbon chain length, structure, thermal characteristics, and crystallinity effect. Scl-PHA polymers, such as PHB, are substantially more rigid than other PHA type polymers, with strengths exceeding $45 \mathrm{MPa}$ and physical and chemical properties equivalent to standard plastics [165]. The disadvantage of this polymer is that it has a low elongation at break and ages rapidly. To improve these qualities, they must be combined with other monomers, such as $3 \mathrm{HP}, 3 \mathrm{HV}$ and $4 \mathrm{HB}$ to reduce rigidity, crystallinity, and ageing [166]. According to Arcos-Hernández et al., the Young (E) modulus ranges are between 779 and $2893 \mathrm{MPa}$ and increase significantly when the $\mathrm{HV}$ content is less than $40 \% \mathrm{~mol}$ [153]. P4HB is a ductile material with good thermal properties and elongation at break of up to $1000 \%$, more than $\mathrm{PHB}$, making it the most elastic homopolymer PHA developed to date [166,167]. Compared to scl-PHA, the second branch of the PHA class, $m c l$-PHA is more elastic, with a higher elongation at break and a lower tensile strength. mcl-PHA is a copolymer with tensile strengths ranging from 5 to $16 \mathrm{MPa}$ and elongation at break ranging from 88 to $360 \%$, consisting of $3 \mathrm{HHx}, 3 \mathrm{HO}$, 3HD, and 3HDD [148]. As different copolymers can change the mechanical strength of PHA, this biopolymer can be used in a variety of combinations that can be designed for a specific application. Due to these characteristics, it is more adaptable than polymers such as PCL, Polyethylene, PLA, etc. [168]. A thorough study of the relationships between PHA crystallinity and polymer composition, compositional distribution, microstructure, and blend composition is expected to inform future polymer development in the medical field [67].

\subsection{Biocompatibility and Biodegradability}

After the structural and chemical determination of the biopolymer, to make it suitable for use in medical applications, it must be biocompatible, bioactive and allow for cell proliferation. Biocompatibility, bioactivity and biodegradability tests are performed in vitro by testing on cell culture and in vivo on laboratory animals. After implantation, the human body has an immune response through the secretion of pro-inflammatory cytokines. The biocompatibility of a PHA polymer is evaluated, and numerous tests were performed to evaluate the cell adhesion of the biomaterial, because many studies have shown that these materials resist for a long time until they are biodegraded [167]. Cell adhesion on scl-PHA films (PHB and its copolymers) was studied using different cell lines, epithelial or osteoblasts. Thus, cell cultures that directly contacted polymer films showed high cell adhesion [169] and, when in contact with the blood, they had an excellent hemocompatibility, activating the coagulation system and having low immune reactions, as the number of lymphocytes tended towards zero [170,171]. Another biocompatibility study on a mclPHA polymer was performed on a heart valve obtained from $\mathrm{PHO}$, wherein vascular cells from the carotid artery of sheep were seeded and implanted in the animal. Following the in vivo test, it was observed that the implant was covered with tissue and did not show any thrombus formation, even having a cell growth rate of $46 \% 7$ days after implantation and a growth rate of up to $116 \%$ after 120 days. Thus, it was concluded that the cardiac devices obtained from PHO could be implanted and have an adequate function for up to 120 days [172]. The same thing could be observed in a stent obtained from PHO in the form of a porous scaffold seeded with vascular cells, tested in vitro for eight days in a simulator. The cells grew through the material's pores and formed a uniform layer, which was viable on the porous scaffold [173]. These results indicate that these polymers can be used to manufacture scaffolds, porous matrices on which host tissue cells can proliferate, and in soft tissue regeneration. 


\section{Brief Review of PHA Biomedical Applications}

Among the various biomaterials available for tissue engineering and therapeutic applications, polyhydroxyalkanoates (PHAs) offer new properties as biomaterials of interest for medical applications due to their high biocompatibility and biodegradability and their various thermal-mechanical properties. The microbial polyesters poly 3-hydroxybutyrate (PHB), polyhydroxyvalerate (PHV) and poly [3-hydroxybutyrate 3-hydroxyvalerate] (PHBV) were most studied for orthopedic applications in recent decades as bone implants, which could form new bone in contact, without a chronic inflammatory response [11].

PHBV has been studied by numerous researchers [174], due to its biocompatibility with bone tissue. By degradation in vivo, PHBV forms D-3-hydroxybutyrate, which is normally found in human blood [175]. The biodegradability of PHA is the result of their stereospecific structure with ester bonds, which can be enzymatically degraded in a biological medium. However, for various medical applications, polyesters need to be improved by functionalization $[99,176]$.

The first commercial product to be approved by the FDA in 2007 was TephaFLEX from Tepha Medical Devices, a linear thermoplastic polyester produced by a recombinant $E$. coli fermentation process. This is an absorbable $\mathrm{P}(4 \mathrm{HB})$ biopolymer, offering sutures that are $35 \%$ stronger than synthetic polydioxanone and $19 \%$ stronger than polypropylene $[177,178]$. Thus, $\mathrm{P}(4 \mathrm{HB})$ can be transformed into a variety of absorbable medical devices, including sutures, patches, grafts, and textiles such as surgical meshes [179].

Phasix ${ }^{\mathrm{TM}}$ mesh is a device made of P4HB [180]. It could become a treatment option for hernia because it has long-term mechanical strength and can prevent further postoperative complications [181,182]. Moreover, the P4HB biopolymer has been successfully implemented in tissue engineering. To increase the variety of uses for PHA-based biomaterials, researchers have investigated derivatization methods such as epoxidation, carboxylation, chlorination, hydroxylation, and pyrolysis [183,184]. Bioactivity, compatibility, biodegradability, hydrophobicity, moldability, and other qualities were improved [185]. Zibiao Li et al. recently investigated designed systems of PHA-based water-soluble polymers, functionalized PHAs with polar groups, or copolymerization of PHAs with hydrophilic components in a variety of polymeric designs [186]. They demonstrated that chemically modified watersoluble PHAs have a considerable impact on material construction and possess remarkable properties, resulting in suitable intelligent biomaterials [187].

Sutures, slings, stents, repair patches, cardiovascular patches, heart valves, orthopedic pins, adhesion barriers, cardiovascular tissue engineering devices, articular cartilage, nerve, tendon, guided tissue repair/regeneration devices, nerve guides, bone marrow scaffolding, and wound dressings are all made with improved PHAs [188,189].

To date, Phantom Fiber ${ }^{\mathrm{TM}}$ is marketed as suture (Tornier Co., Monsanto, MN, USA), MonoMax ${ }^{\circledR}$ as suture (Braun Surgical Co., Ctra. Rubí, Spain), BioFiber ${ }^{\mathrm{TM}}$ as scaffold (P4HB polymer) (Tornier Co.), GalaFLEX as mesh (Galatea Corp., Bromma, Sweden) and Tornier ${ }^{\circledR}$ as a surgical mesh (Tornier Co.) [190].

\section{Conclusions}

Polyhydroxyalkanoates (PHAs) production presents special features, different from other well-known microbial polymers (e.g., polysaccharides). One interesting property of their biological synthesis is the possible use of precursors to induce the biopolymer structure. However, the published results regarding the fermentation yields contain relatively low levels of final concentrations, possibly due to the stress conditions of media composition, which limit the bioprocess performance. New genetic engineered mutant strains, alternative substrates, mixed crops, fed-batch or continuous operation could overcome such restrictions.

Other challenges are the non-water solubility, intracellular character of the biopolymer, requesting complex, and difficult and costly steps of isolation and purification, especially for medical applications requiring purity (surgical reconstruction and tissue engineering, 
involving direct contact with blood). The hydrophobic character could be improved by hydrophilic functionalization, enlarging the area of applications.

Although only polyhydroxybutyrate have been FDA-approved for such medical applications to date [191], their proven favorable properties (immunologically inert, biocompatible, rapid tissue ingrowth, bioresorbable, slow biodegradable tissue scaffolds), as well as a large number of promising studies with other PHAs, justifies the trust in an optimistic outlook regarding the development of these biopolymers.

Author Contributions: Conceptualization, D.-M.M., M.C.E., M.M.; writing-original draft preparation, writing-review and editing, M.C.E., D.-M.M.; supervision, M.M. All authors have read and agreed to the published version of the manuscript.

Funding: This research was funded by Ministry of Research and Innovation, project number PN-19410401 (Contract 34 N/2019).

Institutional Review Board Statement: Not applicable.

Informed Consent Statement: Not applicable.

Data Availability Statement: Data to support statements in this review are available from the corresponding author [Mihaela Carmen Eremia], upon reasonable request.

Acknowledgments: This work was supported by a grant of the Ministry of Research and Innovation, project number PN-19-410401 (Contract 34 N/2019).

Conflicts of Interest: The authors declare no conflict of interest.

\section{References}

1. Rai, R.; Keshavarz, T.; Roether, J.; Boccaccini, A.; Roy, I. Medium chain length polyhydroxyalkanoates, promising new biomedical materials for the future. Mat. Sci. Eng. R. 2011, 72, 29-47. [CrossRef]

2. Lenz, R.W.; Marchessault, R.H. Bacterial Polyesters: Biosynthesis, Biodegradable Plastics and Biotechnology. Biomacromolecules 2005, 6, 1-8. [CrossRef] [PubMed]

3. Lim, S.P.; Gan, S.N.; Tan, I. Degradation of medium-chain-length polyhydroxyalkanoates in tropical forest and mangrove soils. Appl. Biochem. Biotechnol. 2005, 126, 23-32. [CrossRef] [PubMed]

4. Chen, G.; Wang, Y.C. Medical applications of biopolyesters polyhydroxyalkanoates. J. Polym. Sci. 2013, 31, 719-736. [CrossRef]

5. Baptista-Perianes, A.; Malmong, S.M.; Simbara, O.M.M.; Santos, A.R., Jr. In vitro Evaluation of PHBV/PCL Blends for Bone Tissue Engineering. Mater. Res. 2019, 22, e20190338. [CrossRef]

6. Palencia, M.; Lerma, T.; Garcés, V.; Mora, M.; Martínez, J.; Palencia, S. Eco-Friendly Functional Polymers: An Approach from Application-Targeted Green Chemistry, 1st ed.; Elsevier: Amsterdam, The Netherlands, 2021; ISBN 9780128218426.

7. Ray, S.; Kalia, V.C. Biomedical Applications of Polyhydroxyalkanoates. Indian J. Microbiol. 2017, 57, 261-269. [CrossRef]

8. Sangkharak, K.; Prasertsan, P. Screening and identification of polyhydroxyalkanoates producing bacteria and biochemical characterization of their possible application. J. Gen. Appl. Microbiol. 2021, 58, 173-182. [CrossRef]

9. Araujo, P.L.B.; Ferreira, C.R.P.C.; Araujo, E.S. Biodegradable conductive composites of poly (3-hydroxybutyrate) and polyaniline nanofibers: Preparation, characterization and radiolytic effects. Express Polym. Lett. 2011, 5, 12-22. [CrossRef]

10. Kim, D.Y.; Kim, H.C.; Kim, S.Y.; Rhee, Y.H. Molecular characterization of extracellular medium-chain-length poly (3hydroxyalkanoate) depolymerase genes from Pseudomonas alcaligenes strains. J. Microbiol. 2005, 43, $285-294$.

11. Chena, G.-Q.; Wu, Q. The application of polyhydroxyalkanoates as tissue engineering materials. Biomaterials 2005, 26, 6565-6578. [CrossRef]

12. Nigmatullin, R.; Thomas, P.; Lukasiewicz, B.; Puthussery, H.; Roy, I. Polyhydroxyalkanoates, a family of natural polymers, and their applications in drug delivery. J. Chem. Technol. Biotechnol. 2015, 90, 1209-1221. [CrossRef]

13. Insomphun, C.; Chuah, J.A.; Kobayashi, S.; Fujiki, T.; Numata, K. Influence of hydroxyl groups on the cell viability of polyhydroxyalkanoate (PHA) scaffolds for tissue engineering. ACS Biomater. Sci. Eng. 2017, 3, 3064-3075. [CrossRef] [PubMed]

14. Wang, Y.; Bian, Y.Z.; Wu, Q.; Chen, G.Q. Evaluation of three-dimensional scaffolds prepared from poly (3-hydroxybutyrateco-3-hydroxyhexanoate) for growth of allogeneic chondrocytes for cartilage repair in rabbits. Biomaterials 2008, 29, $2858-2868$. [CrossRef] [PubMed]

15. Steinbüchel, A. Polyhydroxyalkanoic acids. In Biomaterials: Novel Materials from Biological Sources, 1st ed.; Byrom, D., Ed.; Palgrave Macmillan: London, UK, 1991; pp. 124-213.

16. Lee, S.Y. Bacterial polyhydroxyalcanoates. Biotechnol. Bioeng. 1996, 49, 1-14. [CrossRef]

17. Haywood, G.W.; Anderson, A.J.; Roger Williams, D.; Dawes, E.A.; Ewing, D.F. Accumulation of a poly(hydroxyalkanoate) copolymer containing primarily 3-hydroxyvalerate from simple carbohydrate substrates by Rhodococcus sp. NCIMB 40126. Int. J. Biol. Macromol. 1991, 13, 83-88. [CrossRef] 
18. Ojumu, T.V.; Yu, J.; Solomon, B.O. Production of polyhydroxyalkanoates, a bacterial biodegradable polymer. Afr. J. Biotechnol. 2004, 3, 18-24. [CrossRef]

19. Imam, S.H.; Greene, R.V.; Zaidi, B.R. Biopolymers Utilizing Nature's Advanced Materials; ACS Symposium Series; American Chemical Society: Washington, DC, USA, 1999; Volume 723.

20. Abe, C.; Taima, Y.; Nakamura, Y.; Doi, Y. New bacterial copolyester of 3-hydroxyalkanoates and 3-hydroxy- $\omega$-fluoroalkanoates produced by Pseudomonas oleovorans. Polym. Commun. 1990, 31, 404-406.

21. Byrom, D. Production of poly- $\beta$-hydroxybutyrate: Poly- $\beta$-hydroxyvalerate copolymers. FEMS Microbiol. Rev. 1992, 103, 247-250. [CrossRef]

22. Curley, J.M.; Hazer, B.; Lenz, R.W.; Fuller, R.C. Production of poly (3-hydroxyalkanoates) containing aromatic substituents by Pseudomonas oleovorans. Macromolecules 1996, 29, 1762-1766. [CrossRef]

23. Doi, Y. Microbial Polyesters; VCH: New York, NY, USA, 1990.

24. Brandl, H.; Knee, E.J., Jr.; Fuller, R.C.; Gross, R.A.; Lenz, R.W. Ability of the phototrophic bacterium rhodospirillum rubrum to produce various poly ( $\beta$-hydroxyalkanoates): Potential sources for biodegradable polyesters. Int. J. Biol. Macromol. 1989, 11, 49-55. [CrossRef]

25. De Koning, G.J.M.; Kellerhals, M.; Van Meurs, C.; Witholt, B. A process for the recovery of poly(hydroxyalkanoates) from Pseudomonads Part 2: Process development and economic evaluation. Bioprocess Eng. 1997, 17, 15-21. [CrossRef]

26. Abe, N.; Ishii, N.; Sato, S.; Tsuge, T. Thermal properties and crystallization behaviors of medium chain length poly (3hydroxyalkanoates)s. Polymer 2021, 53, 3026-3034. [CrossRef]

27. Witholt, B.; Kessler, B. Perspectives of medium chain length poly (hydroxyalkanoates), a versatile set of bacterial bioplastics. Curr. Opin. Biotechnol. 1999, 10, 279-285. [CrossRef]

28. Savenkova, L.; Gercberga, Z.; Nikolaeva, V.; Dzene, A.; Bibers, I.; Kalnin, M. Mechanical properties and biodegradation characteristics of PHB-based films. Process Biochem. 2000, 35, 573-579. [CrossRef]

29. Ishak, K.A.; Velayutham, T.S.; Annuar, M.S.M.; Sirajudeen, A.A.O. Structure-property interpretation of biological polyhydroxyalkanoates with different monomeric composition: Dielectric spectroscopy investigation. Int. J. Biol. Macromol. 2021, 169, 311-320. [CrossRef] [PubMed]

30. Ciesielski, S.; Pokoj, T.; Mozejko, J.; Klimiuk, E. Molecular identification of polyhydroxyalkanoates producing bacteria isolated from enriched microbial community. Pol. J. Microbiol. 2013, 62, 45-50. [CrossRef] [PubMed]

31. Laylock, B.; Hally, P.; Pratt, S.; Werker, A.; Laut, P. The chemomechanical proprieties of microbial polyhydrodyalkanoates. Prog. Polym. Sci. 2013, 38, 536-583. [CrossRef]

32. Parikh, M.; Gross, R.A.; MacCarthy, S.P. The influence of injection molding conditions on biodegradable polymers. J. Inject. Molding Technol. 1998, 2, 30-36.

33. Vroman, I.; Tighzert, L. Biodegradable Polymers. Materials 2009, 2, 307-344. [CrossRef]

34. Galatea Surgical. Available online: https://www.galateasurgical.com/surgical-scaffolds/ (accessed on 3 December 2021).

35. Brigham, C.J.; Sinskey, A.J. Applications of polyhydroxyalkanoates in the medical industry. Int. J. Biotechnol. Wellness Ind. 2012, 1 , 52-60. [CrossRef]

36. Volova, T.; Shishatskaya, E.; Sevastianov, V.; Efremov, S.; Mogilnaya, O. Results of biomedical investigations of PHB and PHB/PHV fibers. Biochem. Eng. J. 2003, 16, 125-133. [CrossRef]

37. Gogolewski, S.; Jovanovic, M.; Perren, S.; Dillon, J.; Hughes, M. Tissue response and in vivo degradation of selected polyhydroxyacids: Polylactides (PLA), poly (3-hydroxybutyrate) (PHB), and poly (3-hydroxybutyrate-co-3-hydroxyvalerate) (PHB/VA). J. Biomed. Mater. Res. 1993, 27, 1135-1148. [CrossRef] [PubMed]

38. Mok, P.-S.; Ch'ng, D.H.-E.; Ong, S.-P.; Numata, K.; Sudesh, K. Characterization of the depolymerizing activity of commercial lipases and detection of lipase-like activities in animal organ extracts using poly(3-hydroxybutyrate-co-4-hydroxybutyrate) thin film. AMB Express 2016, 6, 97. [CrossRef] [PubMed]

39. Verlinden, R.A.J.; Hill, D.J.; Kenward, M.A.; Williams, C.D.; Radecka, I. Bacterial synthesis of biodegradable polyhydroxyalkanoates. J. Appl. Microbiol. 2007, 102, 1437-1449. [CrossRef]

40. Lee, S.; Jeon, E.; Yun, H.S.; Lee, J. Improvement of fatty acid biosynthesis by engineered recombinant Escherichia coli. Biotechnol. Bioprocess Eng. 2011, 16, 706-713. [CrossRef]

41. Wusthuis, R.A.; Kessler, B.; Dielissen, M.P.M.; Witholt, B.; Eggink, G. Biotechnology of Biopolymers; Steinbüchel, A., Doi, Y., Eds.; Wiley: Hoboken, NJ, USA, 2005; Volume 1, p. 244.

42. Akinmulewo, A.B.; Nwiny, O.C. Polyhydroxyalkanoate: A biodegradable polymer. J. Phys. Conf. Ser. 2019, $1378,042007$. [CrossRef]

43. Kniewel, R.; Lopez, O.R.; Prieto, M.A. Biogenesis of medium-chain-length polyhydroxyalkanoates. In Biogenesis of Fatty Acids, Lipids and Membranes. Handbook of Hydrocarbon and Lipid Microbiology; Geiger, O., Ed.; Springer: Cham, Switzerland, 2019.

44. Rottig, A.; Steinbuchel, A. Acyltransferases in bacteria. Microbiol. Mol. Biol. Rev. 2013, 77, 277-321. [CrossRef]

45. The Ecobiomaterial Laboratory. Available online: https://www.ecobiomaterial.com/pha/ (accessed on 16 November 2021).

46. Ramsay, B.; Saracovan, I.; Ramsay, J.; Marchessault, R. Continuous production of long-side-chain poly- $\beta$-hydroxyalkanoates by Pseudomonas oleovorans. Appl. Environ. Microbiol. 1991, 57, 625-629. [CrossRef]

47. Lee, W.H.; Azizan, M.N.M.; Sudesh, K. Effect of culture conditions of poly (3-hydroxybutyrate-co-4-hydroxybutyrate) synthesized by Comamonas acidovorans. Polym. Degrad. Stab. 2003, 84, 129-134. [CrossRef] 
48. Chanprateep, S. Current trends in biodegradable polyhydroxyalkanoates. J. Biosci. Bioeng. 2010, 110, 621-632. [CrossRef]

49. Możejko-Ciesielska, J.; Kiewisz, R. Bacterial polyhydroxyalkanoates: Still fabulous? Microbiol. Res. 2016, 192, 271-282. [CrossRef] [PubMed]

50. Durner, R.; Witholt, B.; Egli, T. Accumulation of poly [(R)-3-hydroxyalkanoates] in Pseudomonas oleovorans during growth with octanoate in continuous culture at different dilution rates. Appl. Environ. Microbiol. 2000, 66, 3408-3414. [CrossRef] [PubMed]

51. Timm, A.; Steinbüchel, A. Fermentation of polyesters consisting of medium-chain-length 3-hydroxyalcanoic acids from gluconate by Pseudomonas aeruginosa and other fluorescent Pseudomonads. Appl. Environ. Microbiol. 1990, 56, 360-376. [CrossRef] [PubMed]

52. Chen, J.; Zhang, L.; Chen, G. Biosynthesis and characterization of polyhydroxyalkanoate copolyesters in Ralstonia eutropha PHB 4 harboring a low-substrate-specificity PHA synthase PhaC2 from Pseudomonas stutzeri 1317. Chin. J. Chem. Eng. 2007, 15, 391-396. [CrossRef]

53. Spiekermann, P.; Rehm, B.; Kalscheuer, R.; Baumeister, D.; Steinbüchel, A. A sensitive, viable-colony staining method using Nile red for direct screening of bacteria that accumulate polyhydroxyalkanoic acids and other lipid storage compounds. Arch. Microbiol. 1999, 171, 73-80. [CrossRef]

54. Tsuge, T.; Watanabe, S.; Sato, S.; Hiraishi, T.; Abe, H.; Doi, Y.; Taguchi, S. Variation in copolymers composition and molecular weight of polyhydroxyalkanoate generated by saturation mutagenesis of Aeromonas caviae PHA synthase. Macromol. Biosci. 2007, 7, 846-854. [CrossRef]

55. Grothe, E.; Chisti, Y. Poly ( $\beta$-hydroxybutyric acid) thermoplastic production by Alcaligenes latus: Behavior of fed-batch cultures. Bioprocess Eng. 2000, 22, 441-449. [CrossRef]

56. Wong, P.A.L.; Cheung, M.K.; Lo, W.L.; Chua, H.; Yu, P.H.F. Effects of types of food waste as carbon source on the molecular weight distributions and thermal properties of the biopolymer (polyhydroxybutyrate) produced by two strains of microorganisms. Mater. Res. Innov. 2005, 9, 4-5. [CrossRef]

57. Pozo, C.; Martinez-Toledo, M.V.; Rodelas, B.; Gonzalez-Lopez, J. Effects of culture conditions on the production of polyhydroxyalkanoates by Azotobacter chroococcum $\mathrm{H} 23$ in media containing a high concentration of alpechin (wastewater from olive oil mills) as primary carbon source. J. Biotechnol. 2002, 97, 125. [CrossRef]

58. Lasemi, Z.; Darzi, G.N.; Baei, M.S. Media optimization for poly ( $\beta$-hydroxybutyrate) production using Azotobacter beijerinckii. Int. J. Polym. Mater. 2012, 62, 265-269. [CrossRef]

59. Shahid, S.; Mosrati, R.; Ledauphin, J.; Amiel, C.; Fontaine, P.; Gaillard, J.-L.; Corroler, D. Impact of carbon source and variable nitrogen conditions on bacterial biosynthesis of polyhydroxyalkanoates: Evidence of an atypical metabolism in Bacillus megaterium DSM 509. J. Biosci. Bioeng. 2013, 116, 302-308. [CrossRef] [PubMed]

60. Valappil, S.P.; Boccaccini, A.R.; Bucke, C.; Roy, I. Polyhydroxyalkanoates in Gram-positive bacteria: Insights from the genera Bacillus and Streptomyces. Antonie Van Leeuwenhoek 2007, 91, 1-17. [CrossRef] [PubMed]

61. Kim, B.S.; Lee, S.C.; Lee, S.Y.; Chang, H.N.; Chang, Y.K.; Woo, S.I. Production of poly(3-hydroxybutyric acid) by fed-batch culture of Alcaligenes eutrophus with glucose concentration control. Biotechnol. Bioeng. 1994, 43, 892-898. [CrossRef] [PubMed]

62. Haas, R.; Jin, B.; Zepf, F.T. Production of poly (3-hydroxybutyrate) from waste potato starch. Biosci. Biotechnol. Biochem. 2008, 72, 253-256. [CrossRef]

63. Quillaguamán, J.; Hashim, S.; Bento, F.; Mattiasson, B.; Hatti-Kaul, R. Poly ( $\beta$-hydroxybutyrate) production by a moderate halophile, Halomonas boliviensis LC1 using starch hydrolysate as substrate. J. Appl. Microbiol. 2005, 99, 151-157. [CrossRef]

64. Koller, M.; Hesse, P.; Bona, R.; Kutschera, C.; Atlic', A.; Braunegg, G. Biosynthesis of High Quality Polyhydroxyalkanoate Coand Terpolyesters for Potential Medical Application by the Archaeon Haloferax mediterranei. Macromol. Symp. 2007, 253, 33-39. [CrossRef]

65. Vladu, M.G.; Petrescu, M.M.; Săvoiu, G.; Spiridon, M.; Eremia, M.C.; Stănescu, P.O.; Lupescu, I. Studies on biosynthesis of polyhydoxyalkanoates (PHA) for biomedical engineering. Studia Univ. Vasile Goldiş Ser. Ştiinţele Vieţii. 2014, $24,57-60$.

66. Lupescu, I.; Eremia, M.C.; Săvoiu, G.V.; Spiridon, M.; Panaitescu, D.; Nicolae, C.; Vladu, M.G.; Stefaniu, A. Comparative studies on isolation of medium-chain-length polyhydroxyalkanoates produced by Pseudomonas spp. strains. Rev. Chim. 2016, 67, 1957-1962.

67. Lee, E.; Jendrossek, D.; Schirmer, A.; Choi, C.; Steinbüchel, A. Biosynthesis of copolyesters consisting of 3-hydroxybutyric acid and medium-chain-length 3-hydroxyalkanoic acids from 1,3-butanediol or from 3-hydroxybutyrate by Pseudomonas sp. A33. Appl. Microbiol. Biotechnol. 1995, 42, 901-909. [CrossRef]

68. Eremia, M.C.; Lupescu, I.; Vladu, M.; Petrescu, M.; Săvoiu, G.; Ștefaniu, A.; Spiridon, M. Studies on poly-3-hydroxyoctanoate biosynthesis by a consortium of microorganisms. Ovidius Univ. Ann. Chem. 2016, 27, 44-47. [CrossRef]

69. Sun, Z.; Ramsay, J.A.; Guay, M.; Ramsay, B.A. Carbon-limited fed-batch production of Medium-chain-length polyhydroxyalkanoates from nonanoic acid by Pseudomonas putida KT2440. Appl. Microbiol. Biotechnol. 2007, 74, 69-77. [CrossRef] [PubMed]

70. Valentin, H.E.; Lee, E.Y.; Choi, C.Y.; Steinbüchel, A. Identification of 4-hydroxyhexanoic acid as a new constituent of biosynthetic polyhydroxyalkanoic acids from bacteria. Appl. Microbiol. Biotechnol. 1994, 40, 710-716. [CrossRef]

71. Jiang, X.; Ramsay, J.A.; Ramsay, B.A. Acetone extraction of mcl-PHA from Pseudomonas putida KT2440. J. Microbiol. Methods 2006, 67, 212-219. [CrossRef] [PubMed]

72. Guo-Qiang, C.; Jun, X.; Qiong, W.; Zengming, Z.; Kwok-Ping, H. Synthesis of copolyesters consisting of medium-chain-length [ß]-hydroxyalkanoates by Pseudomonas stutzeri 1317. React. Funct. Polym. 2001, 48, 107. [CrossRef] 
73. Pantazaki, A.A.; Papaneophytou, C.P.; Pritsa, A.G.; Liakopoulou-Kyriakides, M.; Kyriakidis, D.A. Production of polyhydroxyalkanoates from whey by Thermus thermophilus HB8. Process Biochem. 2009, 44, 847-853. [CrossRef]

74. Vandamme, P.; Coenye, T. Taxonomy of the genus Cupriavidus: A tale of lost and found. Int. J. Syst. Evol. Microbiol. 2004, 54, 2285-2289. [CrossRef]

75. Vaneechoutte, M.; Kampfer, P.; De Baere, T.; Falsen, E.; Verschraegen, G. Wautersia gen. nov., a novel genus accommodating the phylogenetic lineage including Ralstonia eutropha and related species, and proposal of Ralstonia [Pseudomonas] syzygii (Roberts et al. 1990) comb. nov. Int. J. Syst. Evol. Microbiol. 2004, 54, 317-327. [CrossRef]

76. Park, S.J.; Choi, J.I.; Lee, S.Y. Engineering of Escherichia coli fatty acid metabolism for the production of polyhydroxyalkanoates Enzym. Microb. Technol. 2005, 36, 579-588. [CrossRef]

77. Kahar, P.; Agus, J.; Kikkawa, Y.; Taguchi, K.; Doi, Y.; Tsuge, T. Effective production and kinetic characterization of ultra-highmolecular-weight poly (R)-3-hydroxybutyrate in recombinant Escherichia coli. Polym. Degrad. Stab. 2005, 87, 161-169. [CrossRef]

78. Kundu, P.P.; Nandy, A.; Mukherjee, A.; Pramanik, N. Polyhydroxyalkanoates: Microbial Synthesis and Applications. In Encyclopedia of Biomedical Polymers and Polymeric Biomaterials, 1st ed.; Mishra, M., Ed.; CRC Press: Boca Raton, FL, USA, 2015.

79. Steinbüchel, A.; Lütke-Eversloh, T. Metabolic engineering and pathway construction for biotechnological production of relevant polyhydroxyalkanoates in microorganisms. Biochem. Eng. J. 2003, 16, 81-96. [CrossRef]

80. Philip, S.; Keshavarz, T.; Roy, I. Polyhydroxyalkanoates: Biodegradable polymers with a range of applications. J. Chem. Technol. Biotechnol. Int. Res. Proc. Environ. Clean Technol. 2007, 82, 233-247. [CrossRef]

81. Raza, Z.A.; Abid, S.; Banat, I.M. Polyhydroxyalkanoates: Characteristics, production, recent developments and applications. Int. Biodeter. Biodegr. 2018, 126, 45-56. [CrossRef]

82. Muhammadi, S.; Afzal, M.; Hameed, S. Bacterial polyhydroxyalkanoates-eco-friendly next generation plastic: Production, biocompatibility, biodegradation, physical properties and applications. Green Chem. Lett. Rev. 2015, 8, 56-77. [CrossRef]

83. Cercel, M.; Eremia, M.C.; Moscovici, M.; Cornea, P.; Lupescu, I.; Săvoiu, G.; Spiridon, M. Process for Obtaining Biodegradable Polymers by Microbial Path. Patent RO125102A8, 30 July 2014.

84. Fatemeh, T.; Vasheghani-Farahani, E. Biosynthesis of poly- $\beta$-hydroxybutyrate as a biodegradable polymer. Iran. Polym. J. 2003, $12,37-42$

85. Lafferty, R.M. Process for Biotechnological Preparation of Poly-d-(-)-3-Hydroxybutyric Acid. U.S. Patent 4786598, 22 November 1988.

86. Gume, A.M.; Suffian, M.; Annuar, M.; Heidelberg, T. Biosynthesis and characterization of polyhydroxyalkanoates copolymers produced by Pseudomonas putida Bet001 isolated from palm oil mill effluent. PLoS ONE 2012, 7, e45214.

87. De Smet, M.J.; Eggink, G.; Witholt, B.; Kingma, J.; Wynberg, H. Characterization of intracellular inclusions formed by Pseudomonas oleovorans during growth on octane. J. Bacteriol. 1983, 154, 870-878. [CrossRef]

88. Suriyamongkol, P.; Weselake, R.; Narine, S.; Moloney, M.; Shah, S. Biotechnological approaches for the production of polyhydroxyalkanoates in microorganisms and plants-A review. Biotechnol. Adv. 2007, 25, 148-175. [CrossRef]

89. Gumel, A.M.; Annuar, M.S.M.; Heidelberg, T. Growth kinetics, effect of carbon substrate in biosynthesis of mcl-PHA by Pseudomonas putida Bet001. Braz. J. Microbiol. 2016, 438, 427-438. [CrossRef]

90. Sharma, P.K.; Munir, R.I.; Blunt, W.; Dartiailh, C.; Cheng, J.; Charles, T.C.; Levin, D.B. Synthesis and physical properties of polyhydroxyalkanoate polymers with different monomer compositions by recombinant Pseudomonas putida LS46 expressing a novel PHA synthase (PhaC116) enzyme. Appl. Sci. 2017, 7, 242. [CrossRef]

91. Oliveira, G.H.D.; Zaiat, M.; Rodrigues, J.A.D.; Ramsay, J.A.; Ramsay, B.A. Towards the Production of mcl-PHA with enriched dominant monomer content: Process development for the sugarcane biorefinery context. J. Polym. Environ. 2020, 28, 844-853. [CrossRef]

92. Hartmann, R.; Hany, R.; Pletscher, E.; Ritter, A.; Witholt, B.; Zinn, M. Tailor-made olefinic medium-chain-length poly[(R)-3hydroxyalkanoates] by Pseudomonas putida GPo1: Batch versus chemostat production, Biotechnol. Bioeng. 2006, 93, 737-746. [CrossRef] [PubMed]

93. Kim, Y.B.; Lenz, R.W.; Fuller, R.C. Preparation and characterization of poly ( $\beta$-hydroxyalkanoates) obtained from Pseudomonas oleovorans grown with mixtures of 5-phenylvaleric acid and n-alkanoic acids. Macromolecules 1991, 24, 5256-5260. [CrossRef]

94. Gross, R.A.; Kim, O.Y.; Rutherford, D.R.; Newmark, R.A. Cyanophenoxy-containing microbial polyesters: Structural analysis, thermal properties, second harmonic generation and in-vivo biodegradability. Polym. Int. 1996, 39, 205-213. [CrossRef]

95. Kim, G.J.; Lee, I.Y.; Yoon, S.C.; Shin, Y.C.; Park, Y.H. Enhanced yield and a high production of medium-chain-length poly (3-hydroxyalkanoates) in a twostep fed-batch cultivation of Pseudomonas putida by combined use of glucose and octanoate. Enzyme Microb. Technol. 1997, 20, 500-505. [CrossRef]

96. Chee, J.Y.; Yoga, S.S.; Lau, N.S.; Ling, S.C.; Abed, R.M.; Sudesh, K. PHA bacterially produced polyhydroxyalkanoate. Converting renewable resources into 42 bioplastics. In Current Research, Technology and Education Topics in Applied Microbiology and Microbial Biotechnology; Mendez-Vilas, A., Ed.; Formatex Research Center: Badajoz, Spain, 2010; pp. 1395-1404.

97. Lee, S.Y. Plastic bacteria. Progress and prospects for polyhydroxyalkanoate production in bacteria. Trends Biotechnol. 1996, 14, 431-438. [CrossRef]

98. Zinn, M.; Witholt, B.; Egli, T. Occurrence, synthesis and medical application of bacterial polyhydroxyalkanoate. Adv. Drug. Deliv. Rev. 2001, 53, 5-21. [CrossRef] 
99. Rai, R.; Yunos, D.M.; Boccaccini, A.R.; Knowles, J.C.; Barker, I.A.; Howdle, S.M.; Tredwell, G.D.; Keshavarz, T.; Roy, I. Poly-3hydroxyoctanoate $\mathrm{P}(3 \mathrm{HO})$, a medium chain length polyhydroxyalkanoate homopolymer from Pseudomonas mendocina. Biomacromolecules 2011, 12, 2126-2136. [CrossRef]

100. Tanaka, K.; Katamune, K.; Ishizaki, A. Fermentative production of poly-(beta-hydroxybutyric acid) from xylose via L-lactate by a two-stage culture method employing Lactococcus lactis IO-1 and Alcaligenes eutrophus. Can. J. Microbiol. 1995, 41, $257-261$. [CrossRef]

101. Chua, A.S.M.; Takabatake, H.; Satoh, H.; Mino, T. Production of polyhydroxyalkanoates (PHA) by activated sludge treating municipal wastewater: Effect of $\mathrm{pH}$, sludge retention time (SRT), and acetate concentration in influent. Water Res. 2003, 37, 3602-3611. [CrossRef]

102. Lemos, P.C.; Serafim, L.S.; Reis, M.A.M. Synthesis of polyhydroxyalkanoates from different short-chain fatty acids by mixed cultures submitted to aerobic dynamic feeding. J. Biotechnol. 2006, 122, 226-238. [CrossRef]

103. Patnaik, P.R. Perspectives in the modeling and optimization of PHB production by pure and mixed cultures. Crit. Rev. Biotechnol. 2005, 25, 153-171. [CrossRef] [PubMed]

104. Satoh, H.; Mino, T.; Matsuo, T. PHA production by activated sludge. Int. J. Biol. Macromol. 1999, 25, 105-109. [CrossRef]

105. Grothe, E.; Moo-Young, M.; Chisti, Y. Fermentation optimization for the production of ( $\beta$-hydroxybutyric acid) microbial thermoplastic. Enzyme Microb. Technol. 1999, 25, 132-141. [CrossRef]

106. Chee, J.Y.; Tan, Y.; Samian, M.R.; Sudesh, K. Isolation and characterization of a Burkholderia sp. USM (JCM15050) capable of producing polyhydroxyalkanoate (PHA) from triglycerides, fatty acids and glycerols. J. Polym. Environ. 2010, 18, 584-592. [CrossRef]

107. Kaur, G.; Srivastava, A.; Chand, S. Advances in biotechnological production of 1, 3-propanediol. Biochem. Eng. J. 2012, 64, 106-118. [CrossRef]

108. Jiang, X.J.; Sun, Z.; Ramsay, J.A.; Ramsay, B.A. Fed batch production of MCL-PHA with elevated 3-hydroxynonanoate content. AMB Express 2013, 3, 50. [CrossRef]

109. Yang, S.; Li, S.; Jia, X. Production of medium chain length polyhydroxyalkanoate from acetate by engineered Pseudomonas putida KT2440. J. Ind. Microbiol. Biotechnol. 2019, 46, 793-800. [CrossRef]

110. El-Sayed, A.A.; Abdelhady, H.M.; Abdel Hafez, A.M.; Khodair, T.A. Batch Production of Polyhydroxybutyrate (PHB) by Ralstonia eutropha and Alcaligenes latus using Bioreactor Different Culture Strategies. J. Appl. Sci. Res. 2009, 5, 556-564.

111. Lillo, J.G.; Rodriguez-Valera, F. Effects of culture conditions on poly (beta-hydroxybutyric acid) production by Haloferax mediterranei. Appl. Environ. Microbiol. 1990, 56, 2517-2521. [CrossRef]

112. Koller, M.; Muhr, A. Continuous production mode as a viable process-engineering tool for efficient poly (hydroxyalkanoate) (PHA) bio-production. Chem. Biochem. Eng. Q. 2014, 28, 65-77.

113. Koller, M.; Braunegg, G. Potential and prospects of continuous polyhydroxyalkanoate (PHA) production. Bioengineering 2015, 2, 94-121. [CrossRef] [PubMed]

114. Jung, K.; Hazenberg, W.; Prieto, M.; Witholt, B. Two stage continuous process development for the production of medium-chainlength poly (3-hydroxyalkanoates). Biotechnol. Bioeng. 2001, 72, 19-24. [CrossRef]

115. Riedel, S.L.; Brigham, C.J.; Budde, C.F.; Bader, J.; Rha, C.; Stahl, U.; Sinskey, A.J. Recovery of poly(3-hydroxybutyrate-co-3hydroxyhexanoate) from Ralstonia eutropha cultures with non-halogenated solvents. Biotechnol. Bioeng. 2013, 110, 461-470. [CrossRef] [PubMed]

116. Matsumoto, K.; Takase, K.; Aoki, E.; Doi, Y. Synergistic effects of Glu130Asp substitution in the Type II polyhydroxyalkanoate (PHA) synthase: Enhancement of PHA production and alteration of polymer molecular weight. Biomacromolecules 2005, 6, 99-104. [CrossRef] [PubMed]

117. Madkour, M.H.; Heinrich, D.; Alghamdi, M.A.; Shabbaj, I.I.; Steinbüchel, A. PHA recovery from biomass. Biomacromolecules 2013, 14, 2963-2972. [CrossRef] [PubMed]

118. Fei, T.; Cazeneuve, S.; Wen, Z.; Wu, L.; Wang, T. Effective recovery of poly-ß-hydroxybutyrate (PHB) biopolymer from Cupriavidus necator using a novel and environmentally friendly solvent system. Biotechnol. Prog. 2016, 32, 678-685. [CrossRef] [PubMed]

119. Koller, M.; Niebelschütz, H.; Braunegg, G. Strategies for recovery and purification of poly [(R)-3-hydroxyalkanoates] (PHA) biopolyesters from surrounding biomass. Eng. Life Sci. 2013, 13, 549-562. [CrossRef]

120. Jacquel, N.; Lo, C.-W.; Wei, Y.-H.; Wu, H.-S.; Wang, S.S. Isolation and purification of bacterial poly (3-hydroxyalkanoates). Biochem. Eng. J. 2008, 39, 15-27. [CrossRef]

121. Adamus, G.; Kowalczuk, M. Biomass extraction using non-chlorinated solvents for biocompatibility improvement of polyhydroxyalkanoates. Polymers 2018, 10, 731 .

122. Ishak, K.A.; Annuar, M.S.M.; Heidelberg, T.; Gumel, A.M. Ultrasound-assisted rapid extraction of bacterial intracellular mediumchain-length poly (3-hydroxyalkanoates) (mcl-PHAs) in medium mixture of solvent/marginal nonsolvent. Arab. J. Sci. Eng. 2016, 41, 33-44. [CrossRef]

123. Rameshwari, R.; Meenakshisundaram, M. A review on downstream processing of bacterial thermoplastic-polyhydroxyalkanoate. Int. J. Pure Appl. Biosci. 2014, 2, 68-80.

124. Kunasundari, B.; Sudesh, K. Isolation and recovery of microbial polyhydroxyalkanoates. Express Polym. Lett. 2011, 5, 620-634. [CrossRef] 
125. Tamer, I.M.; Moo-Young, M.; Chisti, Y. Disruption of Alcaligenes latus for recovery of poly ( $\beta$-hydroxybutyric acid): Comparison of high-pressure homogenization, bead milling, and chemically induced lysis. Ind. Eng. Chem. Res. 1988, 37, 1807-1814. [CrossRef]

126. Koller, M. Established and advanced approaches for recovery of microbial polyhydroxyalkanoate (PHA) biopolyesters from surrounding microbial biomass. Eurobiotech. J. 2020, 4, 113-126. [CrossRef]

127. Fiorese, M.L.; Freitas, F.; Pais, J.; Ramos, A.M.; de Aragão, G.M.F.; Reis, M.A.M. Recovery of polyhydroxybutyrate (PHB) from Cupriavidus necator biomass by solvent extraction with 1,2-propylene carbonate. Eng. Life Sci. 2009, 9, 454-461. [CrossRef]

128. Heinrich, D.; Madkour, M.H.; Al-Ghamdi, M.A.; Shabbaj, I.I.; Steinbüchel, A. Large scale extraction of poly(3-hydroxybutyrate) from Ralstonia eutropha H16 using sodium hypochlorite. AMB Express 2012, 2, 1-6. [CrossRef]

129. Koller, M.; Bona, R.; Chiellini, E.; Braunegg, G. Extraction of short-chain-length poly-[(R)-hydroxyalkanoates] (scl-PHA) by the "anti-solvent" acetone under elevated temperature and pressure. Biotechnol. Lett. 2013, 35, 1023-1028. [CrossRef]

130. Ramsay, J.A.; Berger, E.; Voyer, R.; Chavarie, C.; Ramsay, B.A. Extraction of poly-3-hydroxybutyrate using chlorinated solvents. Biotechnol. Tech. 1994, 8, 589-594. [CrossRef]

131. Nonato, R.; Mantelatto, P.; Rossell, C. Integrated production of biodegradable plastic, sugar and ethanol. Appl. Microbiol. Biotechnol. 2001, 57, 1-5.

132. Berger, E.; Ramsay, B.A.; Ramsay, J.A.; Chavarie, C.; Braunegg, G. PHB recovery by hypochlorite digestion of non-PHB biomass Biotechnol. Tech. 1989, 3, 227-232. [CrossRef]

133. Hahn, S.K.; Chang, Y.K.; Lee, S.Y. Recovery and characterization of poly (3-hydroxybutyric acid) synthesized in Alcaligenes eutrophus and recombinant Escherichia coli. Appl. Environ. Microbiol. 1995, 61, 34-39. [CrossRef] [PubMed]

134. Kapritchkoff, F.M.; Viotti, A.P.; Alli, R.C.P.; Zuccolo, M.; Pradella, J.G.C.; Maiorano, A.E.; Miranda, E.A.; Bonomi, A. Enzymatic recovery and purification of polyhydroxybutyrate produced by Ralstonia eutropha. J. Biotechnol. 2006, 122, 453-462. [CrossRef] [PubMed]

135. Williams, S.F.; Martin, D.P.; Horowitz, D.M.; Peoples, O.P. PHA applications: Addressing the price performance issue I. Tissue engineering. Int. J. Biol. Macromol. 1999, 25, 111-121. [CrossRef]

136. Kourmentza, C.; Pl'acido, J.; Venetsaneas, N.; Burniol-Figols, A.; Varrone, C.; Gavala, H.N.; Reis, M.A.M. Recent advances and challenges towards sustainable polyhydroxyalkanoate (PHA) production. Bioengineering 2017, 4, 55. [CrossRef]

137. Holmes, P.A.; Lim, G.B. Separation Process. U.S. Patent 4910145A, 20 March 1990.

138. Lu, C.H. Purification and Separation of Polyhydroxyalkanoates from Bacteria. Master's Thesis, Yuan Ze University, Taiwan, 2006

139. Yasotha, K.; Aroua, M.K.; Ramachandran, K.B.; Tan, I.K.P. Recovery of medium-chain-length polyhydroxyalkanoates (PHAs) through enzymatic digestion treatments and ultrafiltration. Biochem. Eng. J. 2006, 30, 260-268. [CrossRef]

140. Horowitz, D.; Brennan, E. Methods for Separation and Purification of Biopolymers. U.S. Patent 20010006802A1, 9 April 2002.

141. Shahid, S.; Corroler, D.; Mosrati, M.; Amiel, C.; Gaillard, J.L. New model development for qualitative and quantitative analysis of microbial polyhydroxyalkanoates: A comparison of Fourier Transform Infrared Spectroscopy with Gas Chromatography. J. Biotechnol. 2021, 329, 38-48. [CrossRef]

142. Tan, G.-Y.A.; Chen, C.-L.; Ge, L.; Li, L.; Wang, L.; Zhao, L.; Mo, Y.; Tan, S.N.; Wang, J.-Y. Enhanced gas chromatography-mass spectrometry method for bacterial polyhydroxyalkanoates analysis. J. Biosc. Bioeng. 2014, 117, 379-382. [CrossRef]

143. Ge, L.; Tan, G.-Y.A.; Wang, L.; Chen, C.-L.; Li, L.; Tan, S.N.; Wang, J.-Y. Determination of monomeric composition in polyhydroxyalkanoates by liquid chromatography coupled with on-line mass spectrometry and off-line nuclear magnetic resonance. Talanta 2016, 146, 107-113. [CrossRef]

144. Grubelnik, A.; Wiesli, L.; Furrer, P.; Rentsch, D.; Hany, R.; Meyer, V.R. A simple HPLC-MS method for the quantitative determination of the composition of bacterial medium chain-length polyhydroxyalkanoates. J. Sep. Sci. 2008, 31, 1739-1744. [CrossRef]

145. Pappalardo, F.; Fragalà, M.; Mineo, P.G.; Damigella, A.; Catara, A.F.; Palmeri, R.; Rescifina, A. Production of filmable mediumchain-length polyhydroxyalkanoates produced from glycerol by Pseudomonas mediterranea. Intern. J. Biol. Macromol. 2014, 65, 89-96. [CrossRef]

146. Mineo, P.; Vitalini, D.; Scamporrino, E.; Bazzano, S.; Alicata, R. Effect of delay time and grid voltage changes on the average molecular mass of polydisperse polymers and polymeric blends determined by delayed extraction matrix-assisted laser desorption/ionization time-of-flight mass spectrometry. Rap. Com. Mass Spec. 2005, 19, 2773-2779. [CrossRef] [PubMed]

147. Cal, A.J.; Kibblewhite, R.E.; Sikkema, W.D.; Torres, L.F.; Hart-Cooper, W.M.; Orts, W.J.; Lee, C.C. Production of polyhydroxyalkanoate copolymers containing 4-hydroxybutyrate in engineered Bacillus megaterium. Int. J. Biol. Macromol. 2021, 168, 86-92. [CrossRef] [PubMed]

148. Gopi, S.; Kontopoulou, M.; Ramsay, B.A.; Ramsay, J.A. Manipulating the structure of medium-chain-length polyhydroxyalkanoate (MCL-PHA) to enhance thermal properties and crystallization kinetics. Int. J. Biol. Macromol. 2018, 119, 1248-1255. [CrossRef] [PubMed]

149. Cha, S.-H.; Son, J.-H.; Jamal, Y.; Zafar, M.; Park, H.-S. Characterization of polyhydroxyalkanoates extracted from wastewater sludge under different environmental conditions. Biochem. Eng. J. 2016, 112, 1-12. [CrossRef]

150. Yasin, A.R.; Ithar, K.A.-M. Biosynthesis of polyhydroxyalkanoate (PHA) by a newly isolated strain Bacillus tequilensis ARY86 using inexpensive carbon source. Biores. Technol. Rep. 2021, 16, 100846. [CrossRef]

151. Chen, S.; Liu, Q.; Wang, H.; Zhu, B.; Yu, F.; Chen, G.-Q.; Inoue, Y. Polymorphic crystallization of fractionated microbial medium-chain-length polyhydroxyalkanoates. Polymer 2009, 50, 4378-4388. [CrossRef] 
152. Tian, J.; Zhang, J.; Wu, Y.; Xue, P. Additive manufacturing of wood flour/polyhydroxyalkanoates (PHA) fully bio-based composites based on micro-screw extrusion system. Mater. Design 2021, 199, 109418. [CrossRef]

153. Arcos-Hernández, M.V.; Laycock, B.; Donose, B.C.; Pratt, S.; Halley, P.; Al-Luaibi, S.; Werker, A.; Lant, P.A. Physicochemical and mechanical properties of mixed culture polyhydroxyalkanoate (PHBV). Eur. Pol. J. 2013, 49, 904-913. [CrossRef]

154. Braunegg, G.; Sonnleitner, B.Y.; Lafferty, R.M. A rapid gas chromatographic method for the determination of poly- $\beta$ hydroxybutyric acid in microbial biomass. Eur. J. Appl. Microbiol. Biotechnol. 1978, 6, 29-37. [CrossRef]

155. Yasser, S.M.; Sulaiman, A.A.; Kholod, A.O.; Saad, A.A.; Mohamed, S.M.; Taher, S. Production and Characterization of Bioplastic by Polyhydroxybutyrate Accumulating Erythrobacter aquimaris Isolated from Mangrove Rhizosphere. Molecules 2020, $25,33-90$.

156. De Eugenio, L.I.; García, P.; Luengo, J.M.; Sanz, J.M.; Román, J.S.; García, J.L.; Prieto, M.A. Biochemical evidence that phaZ gene encodes a specific intracellular medium chain length polyhydroxyalkanoate depolymerase in Pseudomonas putida KT2442. J. Biol. Chem. 2007, 282, 4951-4962. [CrossRef] [PubMed]

157. Furrer, P.; Rentsch, H.D.; Grubelnik, A.; Ruth, K.; Panke, S.; Zinn, M. Quantitative analysis of bacterial medium-chain-length poly ([R]-3-hydroxyalkanoates) by gas chromatography. J. Chromatogr. A. 2007, 1143, 199-206. [CrossRef] [PubMed]

158. Saeed, K.A.; Ayorinde, F.O.; Eribo, B.E.; Gordon, M.; Collier, L. Characterization of partially transesterified poly (betahydroxyalkanoate)s by matrix-assisted laser desorption/ionization time-of-flight mass spectrometry. J. AOAC Int. 2001, 84, 1109-1115. [CrossRef] [PubMed]

159. William, F.; Alvesa, E.C.; Venancioc, F.L. Thermo-analyses of polyaniline and its derivatives. Thermochim. Acta 2010, $502,43-46$.

160. Porter, M.; Yu, J. Monitoring the in situ crystallization of native biopolyester granules in Ralstonia eutropha via infrared spectroscopy. J. Microbiol. Meth. 2011, 87, 49-55. [CrossRef] [PubMed]

161. Arumugam, A.; Sandhya, M.; Ponnusami, V. Biohydrogen and polyhydroxyalkanoate co-production by Enterobacter aerogenes and Rhodobacter sphaeroides from Calophyllum inophyllum oil cake. Bioresour. Technol. 2014, 164, 170-176. [CrossRef]

162. Tran, T.T.; Hamid, Z.A.; Cheong, K.Y. A Review of Mechanical Properties of Scaffold in Tissue Engineering: Aloe Vera Composites. J. Phys. Conf. Ser. 2018, 1082, 012080. [CrossRef]

163. Abdul Samat, A.; Abdul Hamid, Z.A.; Jaafar, M.; Yahaya, B.H. Mechanical Properties and In Vitro Evaluation of Thermoplastic Polyurethane and Polylactic Acid Blend for Fabrication of 3D Filaments for Tracheal Tissue Engineering. Polymers 2021, 13, 3087. [CrossRef]

164. Chen, G.Q. Introduction of Bacterial Plastics PHA, PLA, PBS, PE, PTT, and PPP. In Plastics from Bacteria Microbiology Monographs, Chen, G.Q., Ed.; Springer: Berlin, Germany, 2010; Volume 14.

165. Singh, A.K.; Srivastava, J.K.; Chandel, A.K.; Sharma, L.; Mallick, N.; Singh, S.P. Biomedical applications of microbially engineered polyhydroxyalkanoates: An insight into recent advances, bottlenecks, and solutions. Appl. Microbiol. Biotechnol. 2019, 103, 2007-2032. [CrossRef]

166. Guo, W.; Yang, K.; Qin, X.; Luo, R.; Wang, H.; Huang, R. Polyhydroxyalkanoates in tissue repair and regeneration. Eng. Regen. 2022; in press. [CrossRef]

167. Williams, S.F.; Rizk, S.; Martin, D.P. Poly-4-hydroxybutyrate (P4HB): A new generation of resorbable medical devices for tissue repair and regeneration. Biomed. Technol. 2013, 58, 439-452. [CrossRef] [PubMed]

168. Boesel, L.F.; Le Meur, S.; Thöny-Meyer, L.; Re, Q. The effect of molecular weight on the material properties of biosynthesized poly (4-hydroxybutyrate). Int. J. Biol. Macromol. 2014, 71, 124-130. [CrossRef] [PubMed]

169. Shishatskaya, E.I.; Volova, T.G. A comparative investigation of biodegradable polyhydroxyalkanoate films as matrices for in vitro cell cultures. J. Mater. Sci Mater. Med. 2004, 15, 915-923. [CrossRef] [PubMed]

170. Sevastianov, V.I.; Perova, N.V.; Shishatskaya, E.I.; Kalacheva, G.S.; Volova, T.G. Production of purified polyhydroxyalkanoates (PHAs) for applications in contact with blood. J. Biomater. Sci. Polym. Ed. 2003, 14, 1029-1042. [CrossRef] [PubMed]

171. Shumilova, A.A.; Myltygashev, M.P.; Kirichenko, A.K.; Nikolaeva, E.D.; Volova, T.G.; Shishatskaya, E.I. Porous 3D implants of degradable poly-3-hydroxybutyrate used to enhance regeneration of rat cranial defect. J. Biomed. Mater. Res. A 2017, 105, 566-577. [CrossRef]

172. Sodian, R.; Hoerstrup, S.P.; Sperling, J.S.; Daebritz, S.; Martin, D.P.; Moran, A.M.; Kim, B.S.; Schoen, F.J.; Vacanti, J.P.; Mayer, J.E. Early in vivo experience with tissue-engineered trileaflet heart valves. Circulation 2000, 102, 22-29. [CrossRef]

173. Sodian, R.; Sperling, J.S.; Martin, D.P.; Egozy, A.; Stock, U.; Mayer, J.E., Jr.; Vacanti, J.P. Fabrication of a trileaflet heart valve scaffold from a polyhydroxyalkanoate biopolyester for use in tissue engineering. Tissue Eng. 2000, 6, 183-188. [CrossRef]

174. Kosea, G.T.; Kenara, H.; Hasırcib, N.; Hasırcia, V. Macroporous poly (3-hydroxybutyrate-co-3-hydroxyvalerate) matrices for bone tissue engineering. Biomaterials 2003, 24, 1950.

175. Reusch, R.N. Low molecular weight complexed poly (3-hydroxybutyrate): A dynamic and versatile moleculein vivo. Can. J. Microbiol. 1995, 41, 50-54. [CrossRef]

176. Visakh, P.M. Polyhydroxyalkanoates (PHAs), their Blends, Composites and Nanocomposites: State of the Art, New Challenges and Opportunities. In Polyhydroxyalkanoate (PHA) Based Blends, Composites and Nanocomposites; The Royal Society of Chemistry: London, UK, 2015; pp. 1-17.

177. Martin, D.P.; Williams, S.F. Medical applications of poly-4-hydroxybutyrate: A strong flexible absorbable biomaterial. Biochem. Eng. J. 2003, 16, 97-105. [CrossRef]

178. Rizk, S. Non-Curling Polyhydroxyalkanoate Sutures. U.S. Patent 20060058470A1, 5 January 2010. 
179. Wu, Q.; Wang, Y.; Chen, G.Q. Medical application of microbial biopolyesters polyhydroxyalkanoates. Artif. Cells Blood Substit. Biotechnol. 2009, 37, 1-12. [CrossRef] [PubMed]

180. Van Rooijen, M.M.J.; Jairam, A.P.; Tollens, T.; Jørgensen, L.N.; de Vries Reilingh, T.S.; Piessen, G.; Köckerling, F.; Miserez, M.; Windsor, A.C.J.; Berrevoet, F. A post-market, prospective, multi-center, single-arm clinical investigation of Phasix ${ }^{\mathrm{TM}}$ mesh for VHWG grade 3 midline incisional hernia repair: A research protocol. BMC Surg. 2018, 18, 1-9. [CrossRef] [PubMed]

181. Scott, J.R.; Deeken, C.R.; Martindale, R.G.; Rosen, M.J. Evaluation of a fully absorbable poly-4-hydroxybutyrate/absorbable barrier composite mesh in a porcine model of ventral hernia repair. Surg. Endosc. 2016, 30, 3691-3701. [CrossRef] [PubMed]

182. Molina, C.P.; Hussey, G.S.; Liu, A.; Eriksson, J.; D'Angelo, W.A.; Badylak, S.F. Role of 4-hydroxybutyrate in increased resistance to surgical site infections associated with surgical meshes. Biomaterials 2021, 267, 120493. [CrossRef]

183. Hazer, D.B.; Kilicay, E.; Hazer, B. Poly (3-hydroxyalkanoate)s: Diversification and biomedical applications. Mater. Sci. Eng. C 2012, 32, 637-647. [CrossRef]

184. Kai, D.; Loh, X.J. Polyhydroxyalkanoates: Chemical Modifications toward Biomedical Applications. ACS Sustain. Chem. Eng. 2014, 2, 106-119. [CrossRef]

185. Wiesbrock, F.; Ebner, C.; Stelzer, F.; Weinberg, A.; Kuehn, K.-D. Hybrid polymers for medical applications. Patent WO2012174580A1, 27 December 2012.

186. Li, Z.B.; Yang, J.; Loh, X.J. Polyhydroxyalkanoates: Opening doors for a sustainable future. NPG Asia Mater. 2016, 8 , e265. [CrossRef]

187. Li, Z.B.; Loh, X.J. Water soluble polyhydroxyalkanoates: Future materials for therapeutic applications. Chem. Soc. Rev. 2015, 44, 2865-2879. [CrossRef]

188. Rinaudo, M. Chitin and chitosan: Properties and applications. Prog. Polym. Sci. 2006, 31, 603-632. [CrossRef]

189. Schmidt, D.; Stock, U.A.; Hoerstrup, S.P. Tissue engineering of heart valves using decellularized xenogeneic or polymeric starter matrices. Philos. Trans. R. Soc. B 2007, 362, 1505-1512. [CrossRef]

190. Manavitehrani, I.; Fathi, A.; Badr, H.; Daly, S.; Negahi Shirazi, A.; Dehghani, F. Biomedical Applications of Biodegradable Polyesters. Polymers 2016, 8, 20. [CrossRef] [PubMed]

191. Utsunomia, C.; Ren, Q.; Zimm, M. Poly (4-hydroxybutyrate): Current state and perspectives. Front. Bioeng. Biotehnol. 2020,8 , 257. [CrossRef] [PubMed] 